\title{
Therapy of infected wounds: overcoming clinical challenges by advanced drug delivery systems
}

\author{
Pia Kaiser ${ }^{1}$ - Jana Wächter ${ }^{1} \cdot$ Maike Windbergs $^{1}$ \\ Accepted: 27 January 2021 / Published online: 20 February 2021 \\ (c) The Author(s) 2021
}

\begin{abstract}
In recent years, the incidence of infected wounds is steadily increasing, and so is the clinical as well as economic interest in effective therapies. These combine reduction of pathogen load in the wound with general wound management to facilitate the healing process. The success of current therapies is challenged by harsh conditions in the wound microenvironment, chronicity, and biofilm formation, thus impeding adequate concentrations of active antimicrobials at the site of infection. Inadequate dosing accuracy of systemically and topically applied antibiotics is prone to promote development of antibiotic resistance, while in the case of antiseptics, cytotoxicity is a major problem. Advanced drug delivery systems have the potential to enable the tailor-made application of antimicrobials to the side of action, resulting in an effective treatment with negligible side effects. This review provides a comprehensive overview of the current state of treatment options for the therapy of infected wounds. In this context, a special focus is set on delivery systems for antimicrobials ranging from semi-solid and liquid formulations over wound dressings to more advanced carriers such as nano-sized particulate systems, vesicular systems, electrospun fibers, and microneedles, which are discussed regarding their potential for effective therapy of wound infections. Further, established and novel models and analytical techniques for preclinical testing are introduced and a future perspective is provided.
\end{abstract}

Keywords Wound infection · Bacterial biofilm · Drug delivery systems · Antimicrobial resistance $\cdot$ In vitro wound models Wound dressings

\section{Introduction}

In recent years, the incidence of chronic wounds and severe wound infections has steadily increased. While normal acute wounds heal without therapeutic intervention, chronic wounds are characterized by necrotic tissue, an increased $\mathrm{pH}$ value, and a high concentration of metalloproteases, impeding the course of physiological healing cascades $[1,2]$. Such wounds provide a favorable environment for invasion and proliferation of pathogens, and therefore, wound infections often occur. The prevalence for all chronic wounds was assumed to be 1 to $2 \%$ of the population in 2018 , with healthcare spending up to $\$ 96.8$ billion in the

Maike Windbergs

windbergs@em.uni-frankfurt.de

1 Institute of Pharmaceutical Technology and Buchmann Institute for Molecular Life Sciences, Goethe University Frankfurt, Max-von-Laue-Str. 15, 60438 Frankfurt am Main, Germany
USA [3]. Apart from the economic impact, chronic wounds inflict a significant decrease in the patients' quality of life. One cause for the impaired healing of infected wounds is biofilm formation, a local manifestation of wound infection [4], with an overall prevalence of $75 \%$ (Fig. 1) [5]. Risk factors, such as patient age, malnutrition, obesity, diabetes, as well as smoking promote wound infection (Fig. 1) [6, 7]. Due to the demographic change towards an elderly society with patients with multi-morbidities, there is an increasing health-economic burden and a growing humanitarian interest in effective treatment of wound infections.

While microbes can be found in every open wound $[8$, 9], their presence does not necessarily manifest in a wound infection. A wound infection provokes an immunological host response and is characterized by e.g., local inflammation, swelling, erythema, or pain. The wound microbiome consists of bacterial pathogens as well as of fungi, which either interact with the bacteria and may increase antibiotic resistance or which are even primary pathogens themselves. The most frequently found bacterial strains in infected wounds 
Fig. 1 a Schematic illustration of the wound infection continuum consisting of 5 stages, from the stage of local infection bacteria organize themselves in biofilms. b Biofilms show a prevalence of $75 \%$ in chronic wounds. $\mathbf{c}$ Risk factors promoting wound infection

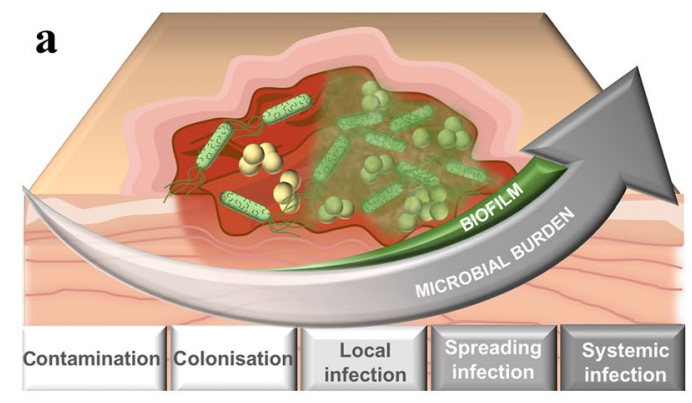

c

- Patient age

- Malnutrition

- Obesity

- Diabetes

- Smoking

- Hospitalisation

period are Staphylococcus aureus and Pseudomonas aeruginosa [10-12], while the most common fungi genus is Candida spp. [13]. The course of infection in a wound can range from colonization of the wound without affecting healing, to a systemic infection with sepsis and organ dysfunction at worst $[8,14]$. This progression, characterized as the wound infection continuum, is divided into contamination and colonization as well as local and spreading infection, eventually culminating in systemic infection (Fig. 1). Local, spreading and systemic infection require either topical and/ or systemic therapeutic intervention $[8,9,15]$. According to the wound infection continuum defined by the International Wound Infection Institute, bacteria organize themselves in biofilms initiated in the stage of local infection [15]. In contrast to free-floating (planktonic) bacterial cells, biofilms are structured, in nature often polymicrobial populations that usually adhere to the wound and are surrounded by extracellular polymeric substances (EPS) [16].

The presence of biofilms poses a particular challenge in the treatment of infected wounds [17]. On the one hand, biofilm bacteria are less susceptible to the human immune defense system due to the mechanical EPS barrier and antiphagocytic properties of the biofilm matrix. On the other hand, biofilms exhibit several mechanisms to develop antibiotic resistance. Firstly, the EPS acts as a mechanical barrier to the permeation and action of antimicrobial agents. Secondly, the biofilm environment enables bacterial communication and thus promotes phenotype changes $[8$, 18]. A tight growth pattern and slow metabolic rates lead to the formation of a heterogeneous population of cells in different growth states, additionally contributing to the increased tolerance against antimicrobial therapy [17]. As a result, biofilms can persist over a long period of time and boost chronification of a wound, as well as cause other local or remote invasive infections by dispersing biofilm fragments, planktonic bacteria, and microcolonies of mature biofilms [8, 14, 18]. Bacteria within biofilms are up to 1000 times more resistant to conventional antimicrobial agents than those in a planktonic state $[8,9,18]$. Due to these resistances and tolerances towards antibiotics and biocides, biofilms impede appropriate treatment and, consequently, prolong the wound healing period [19].

\section{Therapy of infected wounds}

Providing and maintaining a clean and moist wound environment supporting the physiological wound healing process as well as preventing wound infections is considered the primary goal in general wound management. In case of wound infections, first priority is to achieve a reduction in microorganism quantity or virulence in the wound by debridement, therapeutic cleansing, and administration of antimicrobials.

\section{Debridement}

The presence of necrotic tissue and foreign material in wounds provides a medium for infection; hence, its removal through debridement is a major and widely used method to prevent or reduce bacterial growth. The remaining viable tissue is thereby enabled to undergo the normal wound healing phases [20]. Next to the surgical and the conservative sharp debridement, a variety of alternative techniques exists nowadays including mechanical, autolytic, enzymatic, chemical, and biosurgical wound debridement [15, 21].

Regardless of the type of debridement, it is extremely difficult to remove the entire bacterial bioburden, especially in case of biofilms. This is due to the fact that biofilms are strongly adherent to the surrounding tissue and that its formation is not only limited to the wound surface but also appears in deeper layers of the wound bed [22]. Additionally, depending on the present pathogens, mature biofilms can regrow within just $72 \mathrm{~h}$ after debridement, and thus, repetitive debridement is recommended [23]. Even so, debridement alone cannot remove all microorganisms from the wound [24], but the resulting biofilm disruption is associated with a higher susceptibility to outer factors, such as antiseptics or antibiotics [25]. Consequently, debriding the wound in combination with therapeutic cleansing and the application of topical antimicrobial therapeutics is reasonable.

\section{Therapeutic cleansing}

Therapeutic wound cleansing aims to remove problematic excessive or obviously infected exudate, contaminations by 
foreign body, dirt or bacteria, as well as slough or necrotic tissue [26]. According to Leaper et al., the application of therapeutic wound cleansing solutions even has the potential to disrupt biofilms and kill planktonic bacteria as well as other microorganisms while exhibiting low cytotoxic potential [14]. Commonly used cleansing solutions range from potable tap water and sterile normal saline to solutions containing surfactants with or without antimicrobials [14, 27]. Agents such as sterile normal saline are not considered to be effective in removing debris and disrupting biofilms $[26,28]$, therefore, the use of wound cleansing solutions containing surfactants, e.g., undecylenamidopropyl betaine or phenoxyethanol, gained popularity. Due to their amphiphilic structures, surfactants are able to lower the surface tension between the wound bed and the cleansing liquid. The resulting close contact between the liquid and the wound bed facilitates the separation of nonviable tissue and microbial particles from the viable wound bed. In solution, surfactants additionally capture wound debris in micellar structures [27].

\section{Antimicrobial active ingredients}

Antimicrobials include antiseptics and antibiotics, both having the capability to inhibit microbial growth or to kill microorganisms. While antiseptics are nonselective agents showing a wide antimicrobial spectrum, including bacteria, fungi, and viruses, antibiotics have a narrower spectrum of activity. Antibiotics usually target specific sites within bacterial cells and are therefore relatively nontoxic, since they have no influence on human cells. The adverse consequence is their increased susceptibility to a loss of efficacy caused by bacterial resistance. Antiseptics often have multiple sites of antimicrobial action on target cells; thus, the development of bacterial resistance to antiseptics is uncommon [15, 29]. However, it must not be neglected that antiseptic agents often have a toxic effect to human cells, e.g., on fibroblasts and keratinocytes [30].

\section{Antiseptics}

Antiseptic approaches range from physical treatments to application of synthetic as well as natural substances. Physical treatment methods reduce bacterial burden by directly killing bacteria, including cold plasma and low-level laser therapy [31-35], while synthetic and natural substances decrease the bacterial load by either directly killing bacteria or by inhibiting further bacterial growth.

Elemental silver is relatively inert and has no antimicrobial effect. However, an antimicrobial activity develops after highly reactive positively charged silver ions are released, disrupting bacterial cell walls and inhibiting bacterial enzymes. Since they are also binding DNA, they additionally interfere with cell division and replication [36]. Due to a rapid inactivation of silver ions in the extracellular wound fluid, sustained delivery formulations are required [37].

Iodophors include polyvinylpyrrolidone iodine (PVP-I) and the water-soluble modified starch polymer cadexomer iodine. Free iodine as bactericidal component is gradually liberated from the polymers. Compared to aqueous or alcoholic iodine solutions, these carrier systems lead to lower iodine absorption, reduced cytotoxicity and sensitization, and thus to better toleration [38]. Nevertheless, free iodine still exhibits a relatively high cytotoxicity [30] and the additional risk of thyroid dysfunction after systemic absorption renders the use of iodophores controversial.

The antimicrobial effect of octenidine dihydrochloride (ODC) is based on the interaction of the cationic ODC with the negative charges of cell wall and cell membrane components, resulting in destabilization of microorganism membranes [39]. The comparison of its efficacy and cytotoxicity with other disinfectants like PVP-I showed that ODC exhibits a low cytotoxicity and a high microbicidal effect [40].

Polyhexamethylene biguanide (PHMB), also known as polihexanide, is a strong base and interacts with acidic phospholipids in the membrane of microorganisms, resulting in disruption of the membrane and death of the organisms. Since PHMB is further transferred to the cytoplasm, it additionally disrupts the bacterial metabolism [41]. The advantages of PHMB include a broad antimicrobial spectrum with low toxicity and high tissue compatibility [42, 43].

Acetic acid (AA) is a physiologically active substance that kills bacteria in its nondissociated form [44]. Bjarnsholt et al. showed that AA in physiologically tolerable concentrations is capable to completely eradicate bacteria in mature biofilms in vitro [44].

Hypochlorous acid $(\mathrm{HOCl})$ represents another naturally occurring acid that is physiologically produced by neutrophils to destroy pathogens. HOCL irreversibly binds to sulfur- and heme-containing membrane enzymes as well as to structural proteins, resulting in respiratory loss in bacterial cell membrane leading to cell death [45].

A contemporary antimicrobial approach is the application of naturally occurring enzyme systems that produce antimicrobial products. One example is the oxidaseperoxidase system comprised of glucose oxidase and lactoperoxidase stabilized by the aromatic oil guaiacol (GLG-system) that produces free radicals via the release of hydrogen peroxide, thiocyanate, and hypoiodite. These free radicals mediate cell damage in order to kill microorganisms by oxidizing membranes and enzymes, DNA damage and mutations, and the inhibition of membrane transport [46, 47].

Honey and essential oils are prominent examples for naturally derived substances in wound care. Honey, a viscous carbohydrate-rich syrup, enhances wound healing due to a number of factors such as providing a moist 
environment and acting as a mechanical barrier for microbes while simultaneously showing analgesic and antimicrobial effects [48]. Essential oils like lavender oil, tea tree oil, and chamomile oil are defined as volatile mixtures of organic and phytochemical components [49]. Observed antimicrobial, antioxidant, and anti-inflammatory properties are explained by the effect of volatile secondary plant metabolites particularly including mono- and sesquiterpenes. Those constituents probably provoke a loss of cellular membrane integrity of bacterial cells which is further related to the observed antimicrobial effects against a wide range of wound pathogens [50]. However, notable disadvantages remain. Honey and essential oils as well as natural extracts consist of a mixture of components, whose composition highly depends on various outer factors such as the plant origin, the geographical location, season variations, as well as processing and storage conditions [51, 52], while many constituents remain unknown [53]. This leads to difficulties in guaranteeing reproducible composition, quality, and quantity of medical products [54]. Additionally, components of such extracts might provoke irritant, allergic, and cytotoxic adverse effects [55-57].

\section{Antibiotics}

Antibiotic therapy of infected wounds includes topical as well as systemic administration. Antibiotics available for topical therapy include aminoglycosides, sulfonamides, and polypeptide antibiotics, as well as metronidazole, fusidic acid, mupirocin, and retapamulin. Aminoglycosides, e.g., neomycin and gentamicin, are effective against most gram-negative and some gram-positive bacteria species like Staphylococcus aureus; however, neomycin shows no antibacterial activity against Pseudomonas aeruginosa [58]. Like fusidic acid, mupirocin, and retapamulin, aminoglycosides develop their antibacterial effect by inhibiting ribosomal protein synthesis [58]. Fusidic acid penetrates not only intact and damaged skin but also slough and cellular debris and is active against Staphylococcus aureus and some other pathogens [29]. Mupirocin as well shows high activity against Staphylococcus aureus, including some resistant strains, while being ineffective against most gram-negative bacteria [59]. Retapamulin is bacteriostatic against Staphylococcus aureus. By inhibiting the synthesis of folic acid, sulfonamides, e.g., mafenide acetate, silver sulfadiazine, and sulfacetamide sodium, develop a bacteriostatic effect against gram-positive as well as gram-negative bacteria [58]. Polypeptide antibiotics, e.g., polymyxin $\mathrm{B}$, bacitracin, and tyrothricin, disrupt the bacterial cell membrane. While polymyxin $b$ is active against gram-negative bacteria including Pseudomonas species, bacitracin can only be used against gram-positive pathogens. The bactericidal activity of tyrothricin includes a broad spectrum of gram-positive bacteria. It has additionally been shown that the polypeptide antibiotic is effective against methicillin-resistant Staphylococcus aureus with a reduced susceptibility to mupirocin [60]. Metronidazole causes DNA damage in pathogens and acts against anaerobic bacteria as well as some protozoa [58].

A different perspective is posed by antimicrobial peptides (AMP), host-defence-molecules of multicellular organisms, which aim to control microbial proliferation. Due to the prevalence of basic residues, the majority of AMP is cationic in character and presents an amphipathic structure in membrane-like environments [61]. The mechanism of antimicrobial action is mainly based on electrostatic interaction with the anionic phospholipids of the microbial cell membrane [62], which leads to their disintegration and therefore to cell death $[63,64]$. Due to this rather unspecific mechanism of action, the appearance of resistance is less likely compared to conventional antibiotics [65].

\section{Drug delivery strategies for infected wounds}

The use of both antiseptics and topical antibiotics is still often controversially discussed $[29,66]$. For successful elimination of infective microorganisms, antimicrobials must reach the anatomical site of infection in adequate concentrations. This is often impeded by potential instability, rapid degradation in the wound environment, or by bacterial enzymes, as well as due to poor penetration into biofilms. Additionally, poor blood circulation in the majority of chronic wounds poses a particular challenge for systemic antibiotic therapy. Inadequate dosing accuracy of systemic antibiotics at the site of infection may further increase antimicrobial resistance and possibly expose patients to unnecessary risk of adverse side effects. Aside the development of resistance, administration of topical antibiotics entails further disadvantages, such as delayed hypersensitivity reactions, superinfections, and contact dermatitis. In the case of antiseptics, inadequate dosing accuracy can further increase cytotoxicity [10] as well as substance-specific adverse effects. However, suitable drug delivery systems overcome the addressed limitations. An optimal formulation of antimicrobials enables the efficient delivery of active ingredients to the site of infection, at the same time supporting the physiological wound healing process.

\section{State-of-the-art delivery systems}

\section{Semi-solid and liquid formulations}

Traditionally, antiseptic and antibiotic agents have been formulated as semi-solids (ointments, creams, and gels) or 
liquids (solutions, suspensions, and emulsions) for topical application. Compared to liquid dosage forms, semisolid preparations for the treatment of bacterial infections remain longer on the wound surface [67]. Ointments are more occlusive and show greater spreading when compared to creams, and therefore, they are used for dry lesions; conversely, creams are more likely to be used for moist lesions [29]. Semi-solid preparations are poorly suited for heavily exuding wounds. While creams quickly absorb fluid, changing their rheological properties and causing leach out of the wound bed, wound exudate impedes close contact of ointments. Solutions are mainly used for therapeutic cleansing of wounds, since they only have short residence time on the wound site, which is further reduced by an excessive excretion of wound fluid [67].

\section{Wound dressings}

Traditional dry dressings include gauzes, cotton wool, and natural or synthetic bandages. Dry dressings can be used as primary or secondary dressings or as part of a combination of different dressings, with individual functions like absorbing exudate or protecting the wound from external influences. With improved understanding of optimized wound care, the focus shifted towards the development of wound dressings establishing of a moist wound healing environment [67]. Modern wound dressings are additionally capable of enhancing epidermal migration, promoting angiogenesis, providing gas exchange and protecting against pathogens [68].

As there are multiple different types of wounds, a wide range of wound dressings has been developed. Based on wound characteristics and patient condition, a suitable wound dressing must be chosen. Modern dressings are made out of both, natural and synthetic materials, in various physical forms such as films, foams, hydrocolloids, hydrogels, or hydrofibers [67]. Film dressings, historically made out of polyurethane, are extremely flexible, adherent, and transparent. While a certain water vapor transmission rate allows small amounts of exudate to escape through the film, higher amounts of liquid cannot be absorbed and leakage may occur [69]. Polyurethane or silicone foam dressings can absorb large amounts of exudate, but require a secondary dressing for adhesion [70].

Hydrocolloid dressings are made out of gel forming agents such as gelatine, pectin or carboxymethylcellulose, which take up wound exudate, often combined with elastomers and adhesives. They are nonadherent and easy to remove, but their suspected cytotoxic potential limits their application [67, 71].

Hydrogel dressings are crosslinked polymers with hydrophilic structure, such as poly(methacrylates) and polyvinylpyrrolidine. They are capable of establishing a moist wound environment due to their high water content (70-90 \%) and also promote autolytic debridement. Nevertheless, their use is restricted by low mechanical strength and low exudate absorption properties [67].

Wound dressings can additionally serve as delivery systems. Commercially available antiseptic dressings include iodine or PHMB containing dressings as well as dressings impregnated with silver. Modern dressings used for the delivery of various antibiotics include collagen sponges and highly absorbing cotton wool dressings [67, 72], however, regulatory approval of such products and the respective access on the international market is quite limited and dependent on the individual regulations of each country.

\section{Advanced delivery systems}

Unfortunately, all delivery systems currently available on the market show certain drawbacks. In case of semisolid and liquid formulations, the short application period and rapid diffusion processes limit the concentration of antimicrobials at the site of action for the therapeutically intended time interval. Wound dressings impregnated with those formulations can be used to increase the application time; nevertheless, they do neither control the release nor increase the biofilm penetration ability of antimicrobials. In order to meet the requirements mentioned above to a greater extent, a large number of advanced delivery systems has been developed in recent years.

\section{Particulate carriers}

The potential to penetrate into microbial cells and through the EPS of biofilms has led to an increasing interest in nano-sized particles. While nanoparticles (NP) can directly be applied in form of suspensions, their incorporation in secondary formulations (e.g., hydrogels, sponges, and fibers) eases their application. Table 1 provides an overview of recently developed antimicrobial nanoparticles.

Metal or metal oxide nanoparticles are typically used due to their intrinsic antimicrobial activity. The most commonly investigated materials are silver, gold, iron, copper, titanium dioxide, zinc oxide, and cerium oxide [73]. The release of reactive metal ions from the particle surface as well as a generation of reactive oxygen species leading to a membrane disruption of the pathogens are discussed as main mechanisms of their antimicrobial activity [74]. An enhanced efficacy of metal NP instead of materials with greater sizes is attributed to the combined effect of surface attachment and internalization of the NP into microbial cells [75]. Thus, besides the properties of the used material, the particle size as well as shape and surface charge appear to be key factors for determining the predominant mechanism of action [75]. 
Table 1 Summary of recently developed antimicrobial nanoparticles for the treatment of infected wounds

\begin{tabular}{|c|c|c|c|c|c|}
\hline Design of NP & Material & Loading of actives & Secondary formulation & $\begin{array}{l}\text { Test model } \\
\text { Tested bacteria }\end{array}$ & Ref. \\
\hline \multirow[t]{6}{*}{ Metal NP } & Silver & - & Wound dressing & $\begin{array}{l}\text { In vitro: noncell-based, } \\
\text { anti-biofilm assay } \\
\text { In vivo: rats } \\
\text { Tested bacteria: e.g., } S . \\
\text { aureus, } \text { MRSA, } P \text {. aerugi- } \\
\text { nosa, } \text {. coli }\end{array}$ & {$[87-92]$} \\
\hline & Silver & - & Suspension & $\begin{array}{l}\text { In vitro: noncell-based } \\
\text { In vivo: rats, mice } \\
\text { Tested bacteria: e.g., } S . \\
\text { aureus, } M R S A, P . \text { aerugi- } \\
\text { nosa, } \text {. coli }\end{array}$ & {$[81,93]$} \\
\hline & Gold & 6-Amino-penicillanic acid & Wound dressing & $\begin{array}{l}\text { In vitro: noncell-based } \\
\text { In vivo: mice } \\
\text { Tested bacteria: } S \text {. aureus, } \\
\quad \text { E. coli }\end{array}$ & {$[94,95]$} \\
\hline & Gold & Ampicillin, LL37 & Suspension & $\begin{array}{l}\text { In vitro: noncell-based, } \\
\text { anti-biofilm assay } \\
\text { In vivo: rats, mice } \\
\text { Tested bacteria: e.g., } E \text {. } \\
\text { coli, K. pneumoniae, } \\
\text { MRSA }\end{array}$ & [96-98] \\
\hline & Palladium & - & Wound dressing & $\begin{array}{l}\text { In vitro: noncell-based } \\
\text { Tested bacteria: } E \text {. coli }\end{array}$ & [99] \\
\hline & Copper & - & Suspension & $\begin{array}{l}\text { In vitro: noncell-based } \\
\text { Tested bacteria: e.g., } S \text {. } \\
\text { aureus, } P \text {. aeruginosa, } \\
\text { E. coli }\end{array}$ & {$[100]$} \\
\hline \multirow[t]{5}{*}{ Metal oxide NP } & Zinc oxide & - & Wound dressing & $\begin{array}{l}\text { In vitro: noncell-based } \\
\text { Tested bacteria: } S . \text { aureus, } \\
\text { MRSA, E. coli }\end{array}$ & {$[101,102]$} \\
\hline & Titanium dioxide & - & Wound dressing & $\begin{array}{l}\text { In vitro: noncell-based } \\
\text { Tested bacteria: } S . \text { aurues, } \\
\text { P. aeruginosa, E. coli, } \\
\text { B.s ubtilis }\end{array}$ & [103] \\
\hline & Cerium oxide & L-arginin (NO release) & Suspension & $\begin{array}{l}\text { In vitro: noncell-based } \\
\text { Tested bacteria: } S \text {. aureus, } \\
\quad \text { E. coli }\end{array}$ & {$[104]$} \\
\hline & Copper oxide & - & Suspension & $\begin{array}{l}\text { In vitro: noncell-based, } \\
\text { anti-biofilm assay } \\
\text { Tested bacteria: } S \text {. aureus, } \\
\text { P. mirabilis }\end{array}$ & {$[105]$} \\
\hline & Iron oxide & - & Suspension & $\begin{array}{l}\text { In vitro: noncell-based } \\
\text { In vivo: mice } \\
\text { Tested bacteria: MRSA }\end{array}$ & [106] \\
\hline \multirow[t]{3}{*}{ Other inorganic NP } & Silica & Gentamicin sulfate & Wound dressing & $\begin{array}{l}\text { In vitro: noncell-based } \\
\text { Tested bacteria: } S \text {. aureus }\end{array}$ & [107] \\
\hline & Silica & $\begin{array}{l}\text { Ampicillin, NO-releasing } \\
\text { small molecules }\end{array}$ & Suspension & $\begin{array}{l}\text { In vitro: noncell-based, } \\
\text { anti-biofilm assay } \\
\text { In vivo: mice } \\
\text { Tested bacteria: e.g., } S . \\
\text { aureus, } \text { S. } \text { epidermidis, } \\
\text { E. coli }\end{array}$ & {$[83,108]$} \\
\hline & Selenium & - & Wound dressing & $\begin{array}{l}\text { In vitro: noncell-based } \\
\text { Tested bacteria: } S . \text { aureus, } \\
\text { S. epidermidis, } \text { E. coli }\end{array}$ & [109] \\
\hline
\end{tabular}


Table 1 (continued)

\begin{tabular}{|c|c|c|c|c|c|}
\hline Design of NP & Material & Loading of actives & Secondary formulation & $\begin{array}{l}\text { Test model } \\
\text { Tested bacteria }\end{array}$ & Ref. \\
\hline \multirow[t]{7}{*}{ Polymeric NP } & Chitosan & $\begin{array}{l}\text { Erythromycin, cefadroxil, } \\
\text { silver Sulfadiazine }\end{array}$ & Wound dressing & $\begin{array}{l}\text { In vitro: noncell-based } \\
\text { In vivo: rats } \\
\text { Tested bacteria: e.g., E. } \\
\text { coli, S. aureus, P. aerugi- } \\
\text { nos, B. subtilis }\end{array}$ & [110-112] \\
\hline & Chitosan & $\begin{array}{l}\mathrm{Mg} 2+/(-) \text { epigallocate- } \\
\text { chin-3-gallate complex }\end{array}$ & Suspension & $\begin{array}{l}\text { In vitro: noncell-based } \\
\text { In vivo: rats } \\
\text { Tested bacteria: } S \text {. aureus, } \\
\quad \text { E. coli }\end{array}$ & [113] \\
\hline & PLGA & Gentamicin sulfate & Wound dressing & $\begin{array}{l}\text { In vitro: noncell-based, } \\
\text { cell-based } \\
\text { Tested bacteria: } S \text {. aureus, } \\
\text { P. aeruginosa }\end{array}$ & [114] \\
\hline & PLGA & $\begin{array}{l}\text { NO-releasing small } \\
\text { molecules, levofloxacin, } \\
\text { LL37 }\end{array}$ & Suspension & $\begin{array}{l}\text { In vitro: noncell-based, } \\
\text { anti-biofilm assay } \\
\text { In vivo: mice } \\
\text { Tested bacteria: MRSA, } \\
\text { E. coli }\end{array}$ & {$[85,86,115]$} \\
\hline & PCL / pluronic F127 & Chloramphenicol & Suspension & $\begin{array}{l}\text { In vitro: noncell-based } \\
\text { In vivo: mice } \\
\text { Tested bacteria: MRSA }\end{array}$ & [116] \\
\hline & Gelatin & $\begin{array}{l}\text { Selenium (Ru-complex- } \\
\text { modified) }\end{array}$ & Suspension & $\begin{array}{l}\text { In vitro: noncell-based } \\
\text { In vivo: mice } \\
\text { Tested bacteria: } M R S A \text {, } \\
\text { E. coli, } S . \text { aureus, } S . \text { epi- } \\
\text { dermidis, } P \text {. aeruginosa }\end{array}$ & [117] \\
\hline & Polydopamine & Ciprofloxacin & Wound dressing & $\begin{array}{l}\text { In vitro: noncell-based } \\
\text { In vivo: mice } \\
\text { Tested bacteria: } S . \text { aureus, } \\
\text { E. coli, } \text { M. luteus, } P \text {. } \\
\text { vulgaris }\end{array}$ & [118] \\
\hline \multirow[t]{2}{*}{ Other organic NP } & Fullerene & - & Suspension & $\begin{array}{l}\text { In vitro: noncell-based } \\
\text { In vivo: rats } \\
\text { Tested bacteria: } S . \text { aureus, } \\
\quad \text { E. coli }\end{array}$ & [119] \\
\hline & Graphitized carbon black & Vancomycin & Wound dressing & $\begin{array}{l}\text { In vitro: noncell-based } \\
\text { Tested bacteria: } S \text {. aureus, } \\
\text { MRSA }\end{array}$ & {$[120]$} \\
\hline
\end{tabular}

PLGA Poly(lactic-co-glycolic acid), $P C L$ polycaprolactone

Silver NP, as the most investigated metal NP, have been tested against a broad spectrum of wound pathogens. For instance, Kalishwaralal et al. reported an effect against bacterial biofilms. They assumed that silver NP diffuse through water channels into deeper regions of the biofilm and therefore provide an inhibition of bacterial growth while simultaneously inhibiting the production of EPS [76]. It was further proposed that an interruption of bacterial communication pathways occurs which may lead to a reduced biofilm formation [77].
Antimicrobial effects have also been reported for several other metal and metal oxide NP. To enhance the antimicrobial activity or adjust release kinetics, different metal materials are combined in various ways as shown in Fig. 2 [78]. In addition to single metal NP, different metal materials were combined by producing blend NP or NP comprising a core-shell structure with the aim of further enhancing the antimicrobial activity or adjusting release kinetics. Another modification method is doping NP with metal ions to gain an increased potency (Fig. 2) [78]. 
a

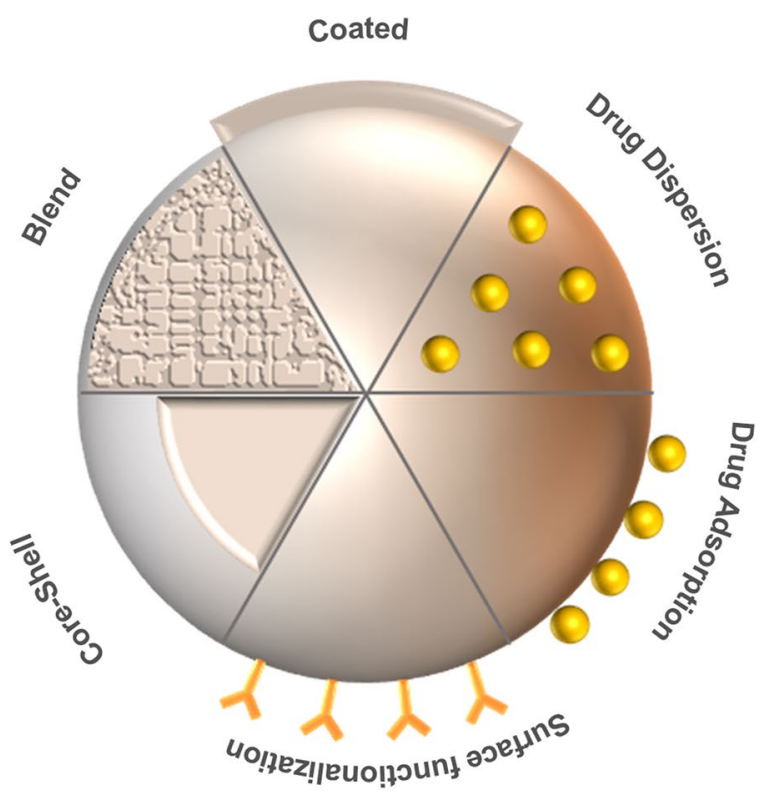

b
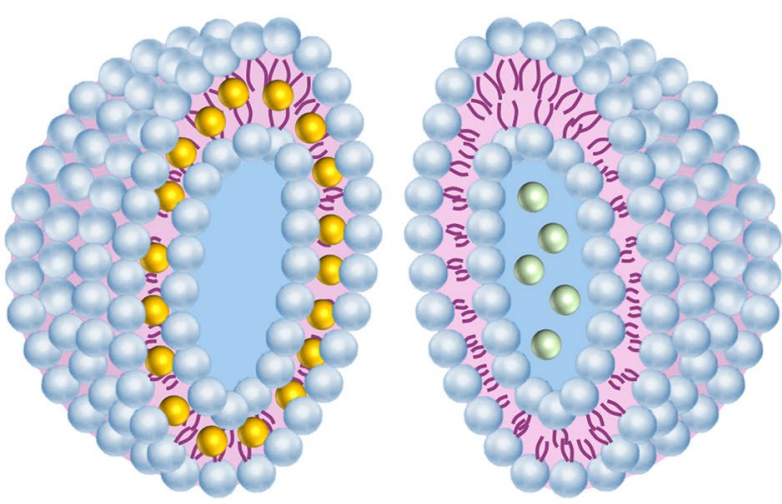

Hydrophobic drug
Other inorganic NP serve as drug delivery systems. In the context of the therapy of infected wounds, special attention has been paid to silica NP, due to the fact that their surface chemistry is well known. Their ratio of inert and active functional groups provides a minimal particle aggregation, while still allowing for surface modification and functionalization [82]. Furthermore, NO-delivering silica NP were developed, for which an antimicrobial effect against planktonic and biofilm bacteria could be shown. However, a cytotoxic effect comparable to standard antiseptic therapy was reported [83].

Additionally, organic polymeric NP, which are typically formed from chitosan or poly-(lactic-co-glycolic acid) (PLGA) and loaded with drugs in different ways (Fig. 2), may be promising drug delivery systems. PLGA is characterized through its biocompatibility, biodegradability, and possibilities of controlling the release kinetic [84]. For investigating the influence of the latter on antibiofilm efficacy, Cheow et al. prepared levofloxacin-loaded PCL and PLGA NP exhibiting different antibiotic release profiles and tested their biofilm susceptibility. They concluded that an observed biphasic release profile provides optimal conditions for antimicrobial activity against bacterial biofilms, with an initial burst release to kill bacteria followed by a sustained release over longer time inhibiting biofilm growth and minimalizing exacerbation [85]. PLGA NP have also been loaded with antimicrobial peptides such as LL37. Cherredy et al. produced such NP and reported an accelerated wound closure in comparison to pure LL37 in vivo which was again attributed to a biphasic release profile. Furthermore, antimicrobial activity against Escherichia coli in vitro, and no effect to the metabolism and proliferation of keratinocytes was reported [86].

\section{Vesicular carriers}

A prominent example for vesicular carriers are liposomes, which are formed out of one or more phospholipid double layers and an aqueous core. The amphiphilicity of their membrane offers the opportunity to incorporate both hydrophilic and lipophilic drugs, while providing high biocompatibility and versatility (Fig. 2). The potential of liposomes to fuse with biological membranes or induce their destabilization leads to an enhanced intracellular drug delivery potency [121]. Various active agents have been incorporated into liposomes (Table 2), of which some are discussed in the following.

As mentioned before, free iodine exhibits a relatively high cytotoxicity [30] with an additional risk of thyroid dysfunction in case of systemic absorption. To circumvent these problems, Reimer et al. proposed a PVP-I liposome hydrogel for antiseptic treatment of wounds. 
Table 2 Overview of antimicrobial liposomal formulations for the treatment of infected wounds

\begin{tabular}{|c|c|c|c|c|}
\hline Material & Loading of actives & Secondary formulation & $\begin{array}{l}\text { Test model } \\
\text { Tested bacteria }\end{array}$ & Ref. \\
\hline $\begin{array}{l}\text { Soybean PC, cholesterol, cyanur- } \\
\text { PE (lysostaphin conjugated) }\end{array}$ & Vancomycin & Suspension & $\begin{array}{l}\text { In vitro: noncell-based } \\
\text { In vivo: mice } \\
\text { Tested bacteria: S.aureus, MRSA }\end{array}$ & [127] \\
\hline $\begin{array}{l}\text { DMPC or DPPC or DSPC, cho- } \\
\text { lesterol }\end{array}$ & Gentamicin & Suspension & $\begin{array}{l}\text { In vitro: noncell-based } \\
\text { Tested bacteria: } P \text {. aeruginosa }\end{array}$ & [124] \\
\hline $\begin{array}{l}\text { DPPC, Cholesterol (+DSPE-PEG- } \\
\text { Mal and PE-Rh) }\end{array}$ & Gentamicin & Chitosan nanofiber mesh & $\begin{array}{l}\text { In vitro: noncell-based } \\
\text { Tested bacteria: } S \text {. aureus, E. coli, } \\
\quad \text { P. aeruginosa }\end{array}$ & [128] \\
\hline $\mathrm{PC}$ & Mupirocin & Chitosan hydrogel & $\begin{array}{l}\text { In vitro: noncell-based } \\
\text { Tested bacteria: e.g., S. epider- } \\
\quad \text { midis, S. aureus, B. subtilis }\end{array}$ & [129] \\
\hline $\begin{array}{l}\text { PC, oleic acid, cholesterol } \\
\text { (pegylated, pyochelin conjugated) }\end{array}$ & $\begin{array}{l}\text { Cefepime, imipenem or ceftazi- } \\
\text { dime }\end{array}$ & Suspension & $\begin{array}{l}\text { In vitro: noncell-based } \\
\text { Tested bacteria: } P \text {. aeruginosa }\end{array}$ & [130] \\
\hline DPPC, MSPC, DSPE-PEG-Mal & Ciprofloxacin & Suspension & $\begin{array}{l}\text { In vitro: noncell-based, anti-bio- } \\
\text { film assay } \\
\text { Tested bacteria: S.aureus }\end{array}$ & [131] \\
\hline $\begin{array}{l}\text { PC, cholesterol, tween } 80 \text {, stear- } \\
\text { ylamine }\end{array}$ & Bacteriophage cocktail & Suspension & $\begin{array}{l}\text { In vivo: mice } \\
\text { Tested bacteria: } S \text {. aureus }\end{array}$ & [132] \\
\hline $\mathrm{PC}$ & PVP-I & Polyacrylic acid hydrogel & $\begin{array}{l}\text { In vitro: noncell-based } \\
\text { Clinical study } \\
\text { Tested bacteria: } \text { S. aureus }\end{array}$ & [122] \\
\hline Soybean PC & Octenidine dihydrochloride & Suspension & $\begin{array}{l}\text { In vitro: noncell-based } \\
\text { Tested bacteria: E.coli }\end{array}$ & [39] \\
\hline $\begin{array}{l}\text { DPPC, DSPC, DSPE-PEG-Mal, } \\
\text { cholesterol }\end{array}$ & $\begin{array}{l}\text { Trichloroiso-cyanuric acid and } \\
\text { cyanuric acid (HClO generating) }\end{array}$ & Suspension & $\begin{array}{l}\text { In vitro: cell-based } \\
\text { In vivo: mice } \\
\text { Tested bacteria: } S . \text { aureus }\end{array}$ & [133] \\
\hline $\begin{array}{l}\text { Soybean PC, polysorbate } 20 \\
\text { (neutral) or add. stearylamine } \\
\text { (cationic) or soybean PC, sodium } \\
\text { deoxycholate (anionic) }\end{array}$ & Curcumin & Suspension & $\begin{array}{l}\text { In vitro: noncell-based } \\
\text { Tested bacteria: } S \text {. aureus, } S \text {. } \\
\text { pyogenes }\end{array}$ & [134] \\
\hline Egg lecithin, cholesterol & Epigallocatechin gallate & Suspension & $\begin{array}{l}\text { In vitro: noncell-based } \\
\text { In vivo: mice } \\
\text { Tested bacteria: MRSA }\end{array}$ & [135] \\
\hline PC, cholesterol & Propolis & Suspension & $\begin{array}{l}\text { In vitro: noncell-based } \\
\text { Tested bacteria: e.g., S. aureus, } \\
\quad \text { E. coli, } P \text {. aeruginosa }\end{array}$ & [136] \\
\hline
\end{tabular}

$P C$ phosphatidylcholine, DMPC 1,2-dimyristoyl-sn-glycero-3-phosphocholine, DPPC dipalmitoylphosphatidylcholine, DSPC 1,2-distearoylsn-glycero-3-phosphocholine, $\quad P E$ phosphatidylethanolamine, DSPE-PEG-Mal 1,2-distearoyl-sn-glycero-3-phosphoethanolamine-N[maleimide(polyethylene glycol)-2000], $P E-R h$ L-a-phosphatidylethanol-amine-N-(lissamine rhodamine B sulfonyl), MSPC 1-stearoyl-2-hydroxylsn-glycero-3-phosphocholine, $P V P-I$ poly(vinyl pyrrolidone)-iodine

In cytotoxicity tests, they were able to demonstrate a significantly higher tolerance of PVP-I liposome complexes compared to aqueous PVP-I preparations with identical iodine concentrations. In vitro antimicrobial efficacy tests resulted in a superior antibacterial efficacy of the $3 \%$ PVP-I liposome hydrogel compared to a $10 \%$ PVP-I ointment. The lower PVP-I content minimizes the potential of systemic absorption, and thus the risk of thyroid dysfunction. The authors conclude that the combination of liposome hydrogel with PVP-I leads to a product that is able to prevent infection, while promoting the wound healing process in form of epithelization due to a moist environment [122].

ODC is another antiseptic for which a liposomal formulation was developed. Not only cleansing solutions but also other ODC agents often contain a surfactant like 2-phenoxyethanol (PE) for the same reasons as discussed before. Since PE has irritating effects, there is need for a new formulation. Szostak et al. introduced a liposomal formulation of ODC, relying on the same positive aspects of liposomes as mentioned above [39]. 
Next to antiseptic agents, liposomes have also been loaded with a variety of antibiotics. In this context, the possibility of protecting liposome-delivered drugs from enzymatic deactivation was reported. Nacucchio et al. prevented the hydrolysis of the betalactam antibiotic piperacillin by liposomal encapsulation [123]. Mugabe et al. verified this observation, as they reported an enhanced antibacterial effect against gentamicin-resistant Pseudomonas aeruginosa from gentamicin-loaded liposomes, proposing that a protection from bacterial enzymes was achieved [124].

However, liposomal formulations struggle with instability issues which can result in drug leakage [84]. The development of polymersomes, another vesicular carrier system, could remedy the instability. By the use of amphiphilic block or graft copolymers with significantly higher molecular weight than lipids, polymersomes form a thicker and therefore much more stable membrane [125]. Polymer nanocapsules have successfully been used to stimulate corneal wound healing and could offer another alternative to liposomal formulations with additional benefits [126].

\section{Fibers}

Fibers with diameters in the nano- to micrometer range have gained increasing interest for wound healing applications. Their fibrous structure closely mimics the human extracellular matrix (Fig. 3), thus favoring cell adhesion, while simultaneously allowing gas exchange, inhibiting microbial infiltration, maintaining a moist environment, and providing high mechanic stability [137].

These fibers are mostly produced by electrospinning, processing a wide range of both natural and synthetic polymers. Of particular interest for the therapy of infected wounds are polymers with inherent antimicrobial activity. In this context, chitosan represents a prominent example. Chitosan is a cationic polysaccharide consisting of a copolymer of glucosamine and $\mathrm{N}$-acetyglucosamine units [138]. Its inherent antimicrobial effect is most likely associated with its cationic nature resulting in interactions with anionic components of bacterial cell membranes, thus inducing an increase of membrane permeability followed by cell leakage and death [139, 140]. Wound dressings consisting of chitosan showed a reduced number of adherent bacteria [141]. Wang et al. further concluded a minimized risk of biofilm formation.

Fibers have been loaded with different antimicrobial agents including classical antiseptics, antibiotics, natural substances, and metal NP (Table 3). Different drug loading methods exist, such as attaching active substances to the surface or embedding them into fibers, as shown in Fig. 3. Attachment of antimicrobial agents to the surface of fibers is achieved by physical or
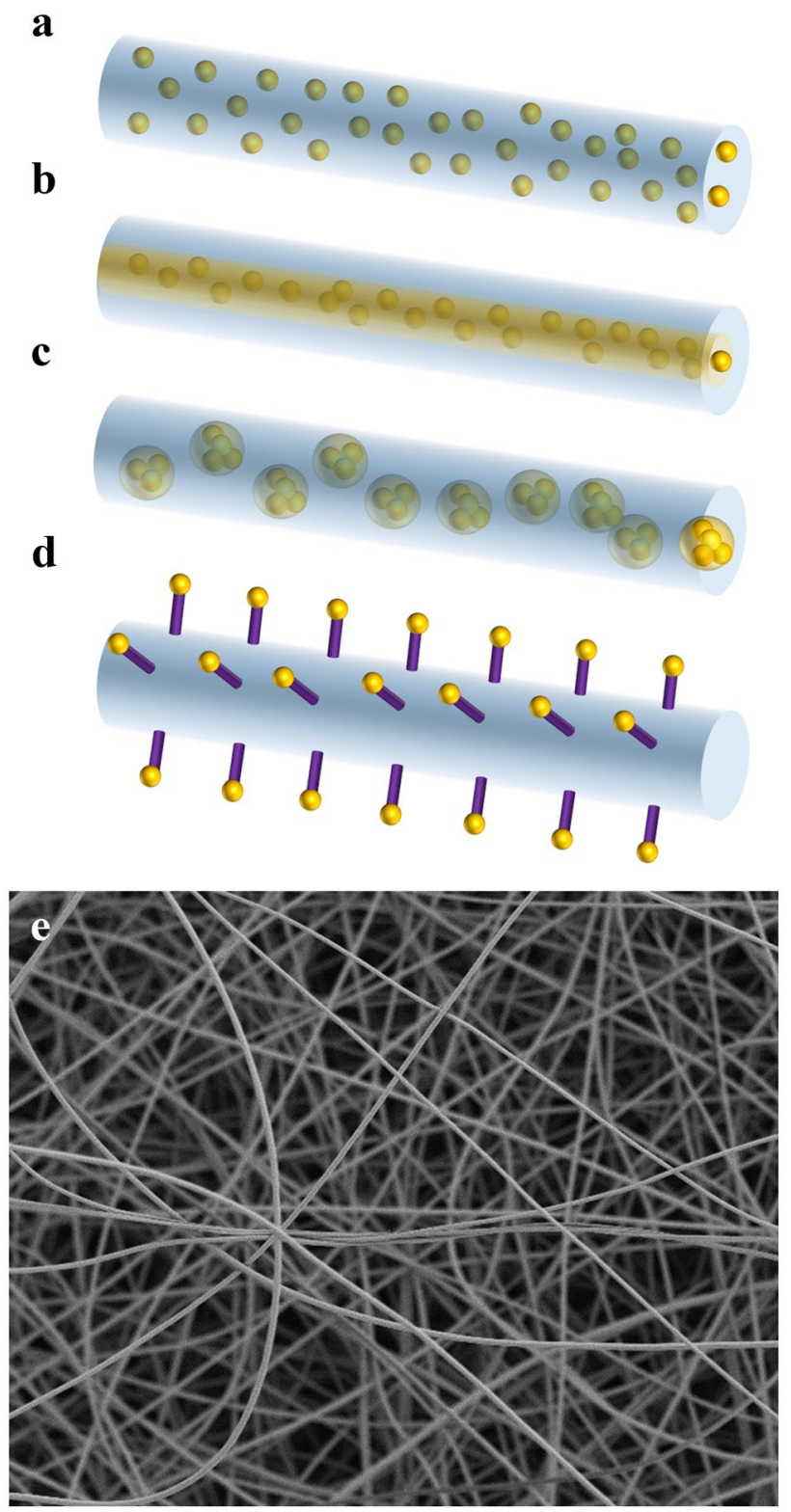

Fig. 3 Drug incorporation strategies into fibers. a Blend electrospinning, a mixture of drugs, polymers and solvents is directly spun. b Co-axial electrospinning, where two solutions are separately spun through a nozzle with two concentric openings. c Emulsion electrospinning, where drug solutions are emulsified. d Attachment of drugs to the surface by physical or chemical immobilization post-electrospinning. e SEM image of electrospun fibers

chemical immobilization. This is especially interesting for nanoparticles such as metal NP [142] and liposomes [128]. Monteiro et al. functionalized electrospun chitosan fibers with thiol groups. Thus, a covalent binding of gentamicin-loaded liposomes is enabled. In this way, advantages of electrospun mats as wound dressings are combined with controlled release properties of liposomes [128]. Incorporation of active agents into fibers can be implemented by various methods, such as 
Table 3 Electrospun fibers tested for therapy of infected wounds

\begin{tabular}{|c|c|c|c|c|}
\hline Design of Fibers & Material & Loading of actives & $\begin{array}{l}\text { Test model } \\
\text { Tested bacteria }\end{array}$ & Ref. \\
\hline Blend electrospinning & PVP & Ciprofloxacin & $\begin{array}{l}\text { In vitro: noncell-based } \\
\text { Ex vivo: human skin } \\
\text { Tested bacteria: } P \text {. aeruginosa }\end{array}$ & [147] \\
\hline Blend electrospinning & Gelatin, ADA & $\begin{array}{l}\text { Gentamicin sulfate and ciprofloxa- } \\
\text { cin }\end{array}$ & $\begin{array}{l}\text { In vitro: noncell-based } \\
\text { In vivo: rats } \\
\text { Tested bacteria: } P \text {. aeruginosa, } S \text {. } \\
\quad \text { epidermidis }\end{array}$ & [148] \\
\hline Blend electrospinning & Zein & Gentamicin & $\begin{array}{l}\text { In vitro: noncell-based } \\
\text { Tested bacteria: } S \text {. aureus, E. coli }\end{array}$ & [149] \\
\hline $\begin{array}{l}\text { Blend electrospinning } \\
\text { Coaxial electrospinning }\end{array}$ & $\begin{array}{l}\text { PLA, PLA-collagen or PLA } \\
\text { (shell), collagen(core) }\end{array}$ & Gentamicin & $\begin{array}{l}\text { In vitro: noncell-based } \\
\text { Tested bacteria: } S \text {. epidermis, } P \text {. } \\
\quad \text { aeruginosa, } E \text {. coli }\end{array}$ & [145] \\
\hline Blend electrospinning & Gelatin (dopamine crosslinked) & $\begin{array}{l}\text { Various polyhydroxy-antibiotics } \\
\text { (e.g., daptomycin, vancomycin) }\end{array}$ & $\begin{array}{l}\text { In vitro: noncell-based } \\
\text { Tested bacteria: e.g., S. aureus, } \\
\text { MRSA, P. aeruginosa, K. pneu- } \\
\text { moniae, E. coli }\end{array}$ & [150] \\
\hline Coaxial electrospinning & Pluronic F127 (core), PCL (shell) & $\begin{array}{l}\text { Cathelicidin peptide 17BIPHE2 } \\
\text { (core) }\end{array}$ & $\begin{array}{l}\text { In vitro: noncell-based, anti-bio- } \\
\quad \text { film assay } \\
\text { Ex vivo: human skin } \\
\text { In vivo: mice } \\
\text { Tested bacteria: e.g., MRSA, A. } \\
\text { baumannii, } P \text {. aeruginosa }\end{array}$ & [151] \\
\hline Blend electrospinning & PU & PHMB & $\begin{array}{l}\text { In vitro: noncell-based } \\
\text { Tested bacteria: } S . \text { aureus }\end{array}$ & [152] \\
\hline Coaxial electrospinning & $\begin{array}{l}\text { PCL (shell) (poly-L-lysine modi- } \\
\text { fied) }\end{array}$ & PVP-I (core) & $\begin{array}{l}\text { In vitro: noncell-based } \\
\text { Tested bacteria: } S \text {. aureus, E. coli }\end{array}$ & [153] \\
\hline Blend electrospinning & PCL & Thymol & $\begin{array}{l}\text { In vitro: noncell-based, } \\
\text { anti-biofilm assay, cell-based } \\
\text { Tested bacteria: } \text { S. aureus, MSSA, } \\
\text { MRSA }\end{array}$ & [154] \\
\hline Blend electrospinning & PVP & Curcumin and cerium nitrate & $\begin{array}{l}\text { In vitro: noncell-based } \\
\text { Tested bacteria: } S . \text { aureus, E. coli }\end{array}$ & [155] \\
\hline Surface functionalization & PVA, lysine (Lys) & Lavender oil, ibuprofen & $\begin{array}{l}\text { In vitro: noncell-based } \\
\text { Tested bacteria: } S . \text { aureus, } P \text {. } \\
\text { aeruginosa }\end{array}$ & [156] \\
\hline Surface functionalization & PCL & Bacteriophage & $\begin{array}{l}\text { In vitro: noncell-based } \\
\text { Tested bacteria: } P \text {. aeruginosa }\end{array}$ & [157] \\
\hline Blend electrospinning & $\begin{array}{l}\gamma \text {-PGA (ethylene glycol- } \\
\text { crosslinked) }\end{array}$ & Photosensitizer & $\begin{array}{l}\text { In vitro: noncell-based } \\
\text { In vivo: mice } \\
\text { Tested bacteria: } S . \text { aureus, E. coli }\end{array}$ & [158] \\
\hline
\end{tabular}

$P V P$ polyvinylpyrrolidone, $A D A$ alginate dialdehyde, $P L A$ polylactic acid, $P C L$ polycaprolactone, $P U$ polyurethane, $P V A$ poly(vinyl alcohol), $\gamma$-PGA poly( $\gamma$-glutamic acid), $P H M B$ polyhexamethylene biguanide, $P V P$-I poly(vinyl pyrrolidone)-iodine

blend electrospinning, emulsion electrospinning, or co-axial electrospinning. Blend electrospinning is defined by directly spinning a mixture of polymers, actives, and solvents. Spinning of an emulsion in case of emulsion electrospinning can lead to the formation of either a preserved emulsion structure restricted to the inner phase or a core-shell structure through coalescing $[137,143]$. Co-axial electrospinning is a direct method to produce fibers with a core-shell structure. In this approach a nozzle with two concentric openings is needed, which inhibits the contact between both solutions until they exit the syringe (Fig. 3) [144].
The release kinetic of antimicrobials can highly impact their efficacy against bacterial biofilms. To evaluate the influence of drug loading methods on the release kinetic of antibiotics, Torres-Giner et al. encapsulated gentamicin in pure polylactide fibers (PLA), in a blend of PLA and collagen as well as in coaxial fibers consisting of a PLA shell and a collagen core. The desired biphasic sustained release profile could be achieved with core-shell structured fibers. Incorporating the hydrophilic drug gentamicin into pure hydrophobic PLA resulted in a slow release, as a portion of gentamicin was retained inside the hydrophobic structure. The fastest release is observed using a 
PLA/collagen blend. The water solubility of collagen leads to a porous structure and enables the diffusion of water molecules into the fibers and therefore the release of gentamicin [145]. The observed burst effect of blend electrospun fibers is consistent with another study where tetracycline was incorporated in PVA/ chitosan blend fibers [146].

\section{Microneedles}

The application of microneedles (MN) is an emerging transdermal drug delivery approach. The microscale needles exhibit a length of 25 to $2000 \mu \mathrm{m}$ and are arranged on a patch with up to hundreds of needles per centimeter (Fig. 4). It has been shown that MN successfully penetrate the outer layers of skin, while, due to their small size, they do not provoke any pain stimulus and minimize damage to the skin barrier function $[159,160]$. The incorporation of active ingredients into microneedles can take place in different ways as presented in Fig. 4. MN made of metal, silicone, or ceramic can be coated with a film containing active ingredients. Hydrogel-forming MN provide another possibility, their gelation enables the diffusion of active ingredients from an attached patch into the skin. A third possibility is posed by dissolving MN consisting of polysaccharides or other polymers in which the drug is encapsulated [161]. While necrotic tissue in infected wounds and the mechanical barrier provided by biofilms often hinder the administration of antimicrobial agents, $\mathrm{MN}$ appear to present a promising drug delivery system, since they are able to penetrate those barriers. Recently, several studies examined the effects of $\mathrm{MN}$ in combination with various antimicrobial agents on microorganisms and biofilms (Table 4).

$\mathrm{Xu}$ et al. fabricated patches with self-dissolvable MN and loaded the needle tips with gelatine NP containing chloramphenicol. After the MN were dissolved in the wound area, the gelatine NP were released and disassembled by the gelatinase produced by the active bacterial community of the biofilm. In comparison to chloramphenicol in free solution, they found that the MN-mediated treatment was more effective in treating Vibrio vulnificus biofilms [162]. A similar approach was shown by Permana et al., who investigated the antimicrobial efficacy of chitosan-coated NP loaded with doxycycline and applied with the help of MN [163].

The combination of an electrospun fiber dressing with dissolvable MN arrays and AMP was reported by Su et al. This antimicrobial dressing was not only able to eradicate methicillinresistant Staphylococcus aureus (MRSA) biofilms in different wound infection models after daily treatment without applying surgical debridement, but also to completely remove a dual-species biofilm of Pseudomonas aeruginosa and MRSA in an ex vivo human skin infection model [164]. a

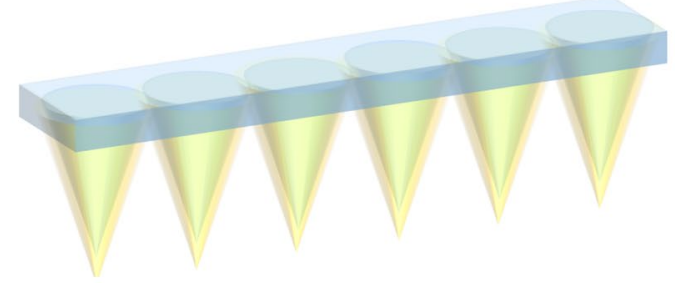

b

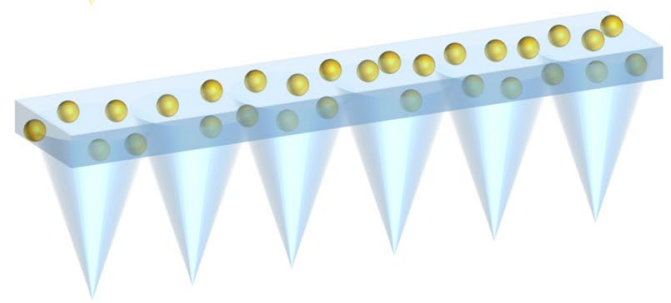

c
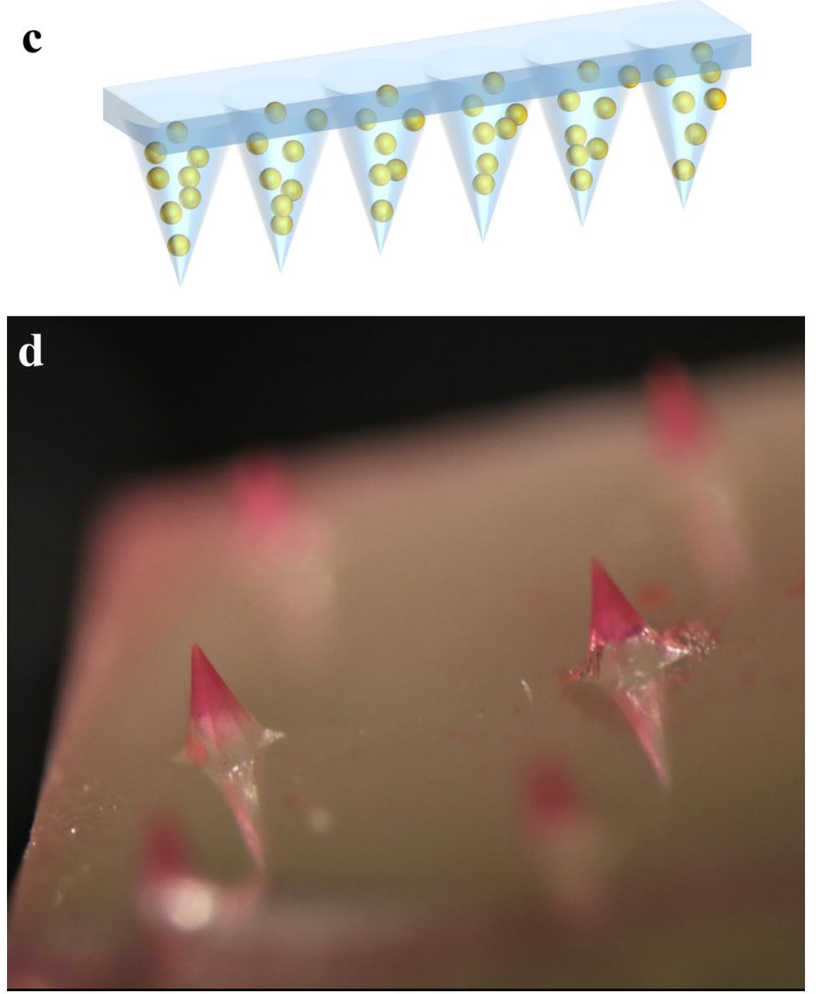

Fig. 4 Drug incorporation strategies into microneedles. a Coated microneedles. b Hydrogel-forming microneedles, the drug diffuses from the patch through the microneedles. c Dissolving microneedles, in which the drug is encapsulated. d LM image of dye-loaded microneedles

Against the background of the state-of-the-art drug delivery systems, the advanced drug delivery systems have some considerable advantages. The penetration into biofilms can be improved by both NP and MN, while liposomes enable the intracellular transport of antimicrobials. Bacterial resistance mechanisms can be overcome by specific vesicular carriers. Additionally, the use of NP and liposomes allows for targeting. Release kinetics can easily be adjusted using polymeric NP or 
Table 4 Summary of studies regarding the effects of MN in combination with antimicrobial agents on microorganisms and biofilms

\begin{tabular}{|c|c|c|c|c|}
\hline Microneedle design & Fabrication materials & Loading & Test model/tested bacteria & Ref. \\
\hline Dissolving MNs & PVA, PVP & $\begin{array}{l}\text { Silver NPs incorporated into } \\
\text { bacteria-responsive microparticles } \\
\text { (MP) }\end{array}$ & $\begin{array}{l}\text { In vitro: noncell-based, anti-biofilm } \\
\text { assay } \\
\text { Ex-vivo: rat skin } \\
\text { Tested bacteria: } S \text {. aureus, P. aer- } \\
\text { uginosa }\end{array}$ & [165] \\
\hline Dissolving MNs & Manuka honey & - & $\begin{array}{l}\text { In vitro: noncell-based } \\
\text { Tested bacteria: MRSA }\end{array}$ & [166] \\
\hline Dissolving MNs & PVA, PVP & Carvacrol-PCL-NPs & $\begin{array}{l}\text { In vitro: noncell-based } \\
\text { Ex-vivo: pig skin } \\
\text { Tested bacteria: } S \text {. aureus, P. aer- } \\
\quad \text { uginosa }\end{array}$ & [167] \\
\hline Two-layered dissolving MNs & $\begin{array}{l}\text { PVA, PVP covered } \\
\text { with PVP, glycerol }\end{array}$ & $\begin{array}{l}\text { Doxycycline loaded PLGA and PCL } \\
\text { NPs }\end{array}$ & $\begin{array}{l}\text { In vitro: noncell-based, anti-biofilm } \\
\quad \text { assay } \\
\text { Ex-vivo: pig skin } \\
\text { Tested bacteria: } S \text {. aureus, P. aer- } \\
\quad \text { uginosa }\end{array}$ & [163] \\
\hline Dissolving MNs & PVP & Antimicrobial peptides & $\begin{array}{l}\text { In vitro: noncell-based } \\
\text { Ex vivo: human skin } \\
\text { In vivo: mice } \\
\text { Tested bacteria: MRSA, } K \text {. pneumo- } \\
\text { niae, } \text { A. baumannii, } P \text {. aeruginosa }\end{array}$ & [164] \\
\hline Dissolving MNs & Chitosan, Zn2+ & - & $\begin{array}{l}\text { In vitro: noncell- based, anti-biofilm } \\
\text { assay } \\
\text { Tested bacteria: } S . \text { aureus, E. coli }\end{array}$ & [168] \\
\hline $\begin{array}{l}\text { Dissolving MNs with loaded needle } \\
\text { tips }\end{array}$ & PVP & $\begin{array}{l}\text { Chloramphenicol bearing, gelati- } \\
\text { nase-sensitive gelatin NPs }\end{array}$ & $\begin{array}{l}\text { In vitro: anti-biofilm assay } \\
\text { Tested bacteria: } V \text {. vulnificus }\end{array}$ & [162] \\
\hline Dissolving MNs & Gantrez ${ }^{\circledR}$ AN-139 & Methylene blue & $\begin{array}{l}\text { In vitro: noncell-based, anti-biofilm } \\
\text { assay } \\
\text { Tested bacteria: S. aureus, E. coli, } \\
\text { C. albicans }\end{array}$ & [160] \\
\hline Dissolving MNs & Hyaluronic acid & Green tea extract & $\begin{array}{l}\text { In vitro: noncell-based } \\
\text { In vivo: rats } \\
\text { Tested bacteria: } \text { E. coli, } \text { S. typh- } \\
\text { imurium, } P \text {. putida, B. subtilis, } S \text {. } \\
\text { aureus }\end{array}$ & [169] \\
\hline
\end{tabular}

$P V A$ polyvinyl alcohol, $P V P$ polyvinylpyrrolidone, $P C L$ polycaprolactone, $P L G A$ poly(lactic-co-glycolic acid)

fibers. Fibers further promote physiological wound healing through their structure. However, the field of innovative applications has yet not fully been exploited. Although many promising systems have been developed, the pathophysiological situation of infected wounds as well as requirements for "real life" clinical application are often insufficiently considered, and the studies remain on an academic level lacking transfer potential towards clinical applications. More interdisciplinary research is urgently needed for the development of drug delivery systems that are not only effective in artificial test environments but have the potential to become next-generation wound therapeutics.

\section{Preclinical testing of novel drugs and formulations for infected wounds}

As mentioned above, the simulation of an infected wound scenario represents a particular challenge. Due to ethical and regulatory reasons, wound healing studies with novel drugs or formulations cannot be performed in humans. Therefore, predictive models of human skin wounds, especially in the infected state, are required. Additionally, there is a strong need for appropriate analytical techniques to evaluate the therapeutic effect and potential side effects. 


\section{Models of infected human skin wounds}

In vivo, ex vivo, and in vitro models have been developed to imitate infected human skin wounds (Fig. 5). Next to the possibility of investigating the wound healing process, chronification of wounds as well as biofilm formation, such models allow for the testing of novel wound healing agents or drug delivery systems. During preclinical testing, animal models are used, including mice, rats, rabbits, and pigs [170]. Even though in vivo models represent a complete organism's reactions in terms of wound healing, infection, and therapeutic success of applied medications, the translatability of animal data to the situation in the human body is limited. Especially in rodents like mice and rats, which are predominantly used as models, the immune response is significantly different and wound healing is governed by an additional layer of muscles, which is absent in the human body [171]. In this respect, pig models show more similarities to humans [172], but their use is limited due to high costs. Simultaneously, ethical concerns remain [173] and the variability between experiment conditions and different animals results in limited reproducibility and comparability between different animal studies.

Ex vivo infected wound models provide a promising alternative. Porcine or murine tissues are typically used, but models based on human skin also exist [174]. The skin is cultured in an artificial environment (e.g., hydrogel) that offers more controlled experimental conditions [175].

Cell-based in vitro models include two-dimensional cell monolayers and more sophisticated three-dimensional tissue engineered human skin equivalents. Hereby, cell monolayers of keratinocytes offer a very simple method used for basic research purposes, but cannot mimic bacterial invasion and interaction with different cell types or the extracellular matrix that occur in vivo $[173,175]$. In contrast, complex three-dimensional models show improved simulation of the complex microenvironment of human infected wounds, but unlike human skin they usually do not contain immune cells as well as blood cells and hair follicles [176, 177].

For simulating an infection, the wound is inoculated with one or more pathogens (Fig. 5), whereby selection of an appropriate concentration for inoculation remains difficult as high doses may induce an increased mortality, while inoculation of too few bacteria may not represent the true status presented in infected wounds and in case of in vivo models pathogen elimination by the hosts immune system may occur [175].

Most models only represent an acute state of infection with planktonic bacteria, while no biofilm formation occurs. This is due to the fact that considering biofilm formation complicates the modeling of infected wounds and requires a prolonged observation period. Still, the main challenge is maintaining an infected wound model over a prolonged period of time in terms of the length of time for chronic wound infections and providing an adequate supply of nutrients and oxygen [175]. To circumvent the need of living cells, static or dynamic in vitro biofilm models can be used to test novel antimicrobial agents (Fig. 5). In vitro biofilm models allow a cheap and easy access to high-throughput experiments. However, a lack of interactions between biofilm and host's microenvironment exists leading to a questionable physiologic relevance.

\section{Analytical techniques}

The analytical assessment of wound healing can be achieved using a variety of different techniques, with emphasis on optical methods ranging from digital photography to microscopy approaches. Complementary, microbiological assays and DNA sequencing techniques can be used to quantify the bacterial burden.
Fig. 5 Schematic overview of models of infected human skin wounds: planktonic bacteria can be used to either infect in vivo, in vitro, or ex vivo wound models directly or to develop in vitro static or dynamic biofilm models; precultured bacterial biofilms can also infect wound models

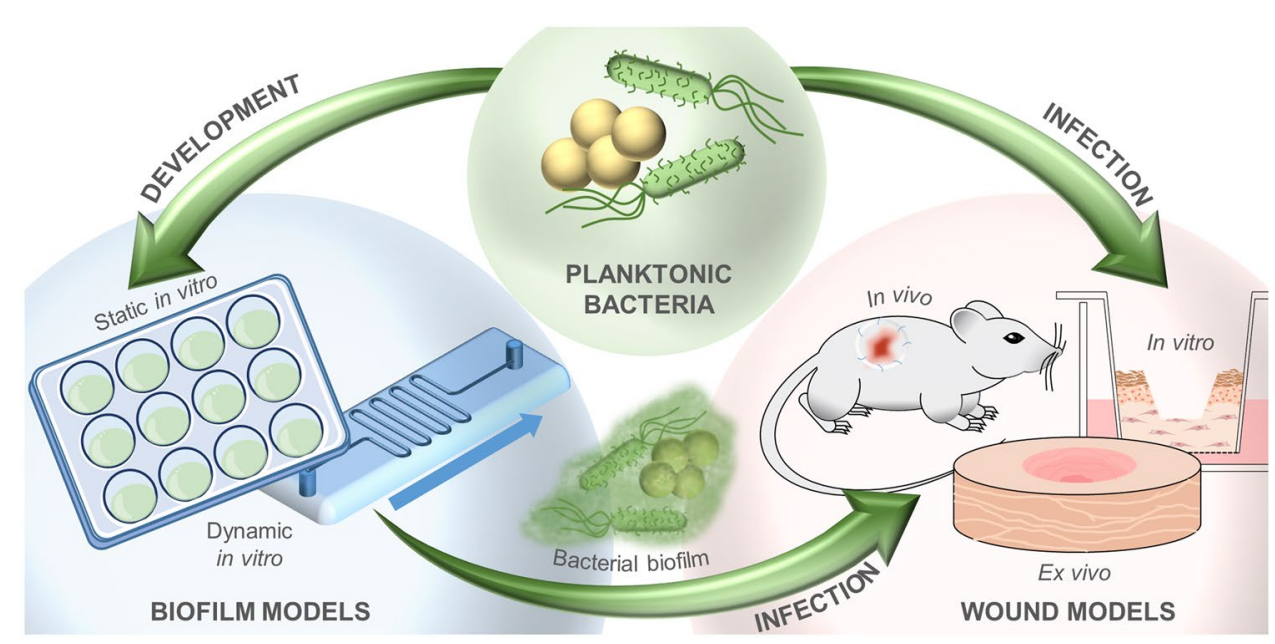


Light microscopy (LM) is commonly used for histological examination of sample sections. Since it is a low-cost and robust method, the application is widespread [15]. HarrisonBalestra et al. used LM in combination with a modified Congo red staining technique to demonstrate the sequential development of mature biofilm grown by wound-isolated Pseudomonas aeruginosa. They could show that the EPS of the developing biofilm was visible after $5 \mathrm{~h}$ and exhibited the characteristics of a mature biofilm by $10 \mathrm{~h}$ [178]. Since staining only allows for a presumptive identification of species, it is impossible to obtain a definitive identification of microbial species with LM. In addition, its use is limited to microbial cell suspensions and thin tissue sections.

Fluorescence in situ hybridization (FISH) uses fluorescentlabelled complementary DNA, RNA, or modified nucleic acid strands to identify and, if applicable, locate a specific DNA or RNA within a tissue or in a microbial suspension. Imaging is possible with either a fluorescence microscope (FM) or by confocal laser scanning microscopy (CLSM). While the use of FM is limited to microbial cell suspensions and thin tissue sections, CLSM enables the examination of tissue blocks and the reconstruction of 2D or 3D structures. Almeida et al. used a modified FISH method in combination with CLSM to quantify and visualize the different microorganisms in mixed biofilm populations and were able to identify different microbial layers within the biofilm [179]. Further, FISH and CLSM have successfully been used to evaluate the effect of topical ointments on biofilms formed by Pseudomonas aeruginosa and Staphylococcus aureus [180]. Of course, FM and CLSM can be used with other fluorescent markers [181]; however, the use is limited to the observation of fluorescent structures, while nonfluorescent structures will be missed [15].
Scanning electron microscopy (SEM) enables the identification of biofilm by imaging the surface layers and providing insight into the 3D structure. In vitro biofilms can be investigated regarding size, arrangement, and architecture of cell aggregates and the extracellular matrix [182, 183]. Similar structures in samples from chronic nonhealing wounds in humans can indicate microbial biofilm formation [184]. Since SEM generally requires dehydration of the samples, it is not possible to examine living material; additionally, the dehydration may cause changes in the samples [15].

All these analytical methods have a destructive sample preparation in common, either sectioning and staining or dehydrating. Therefore, the analysis is limited to only one point in time and there is a need for nondestructive methods. Staining has the additional disadvantage that a detailed knowledge of the sample is required so that unknown states can only be discovered by chance. A noninvasive analysis technique widely used in clinical practice is digital photography. The progress of wound healing can be assessed by evaluating the images; however, the photography is limited to superficial observation.

An emerging technology is optical topography (OT), which enables additional analysis of wound bed volume. Based on the white light reflection, OT enables the nondestructive three-dimensional visualization of the entire defect area within a wound (Fig. 6). Planz et al. reported great potential of this technique for monitoring wound healing by successive scanning of the wound geometry [185]. OT thus represents a technique with which the influence of biofilms on wound healing can be observed noninvasively and over a longer period of time.

Confocal Raman microscopy (CRM) poses another emerging label-free and noninvasive technique, which

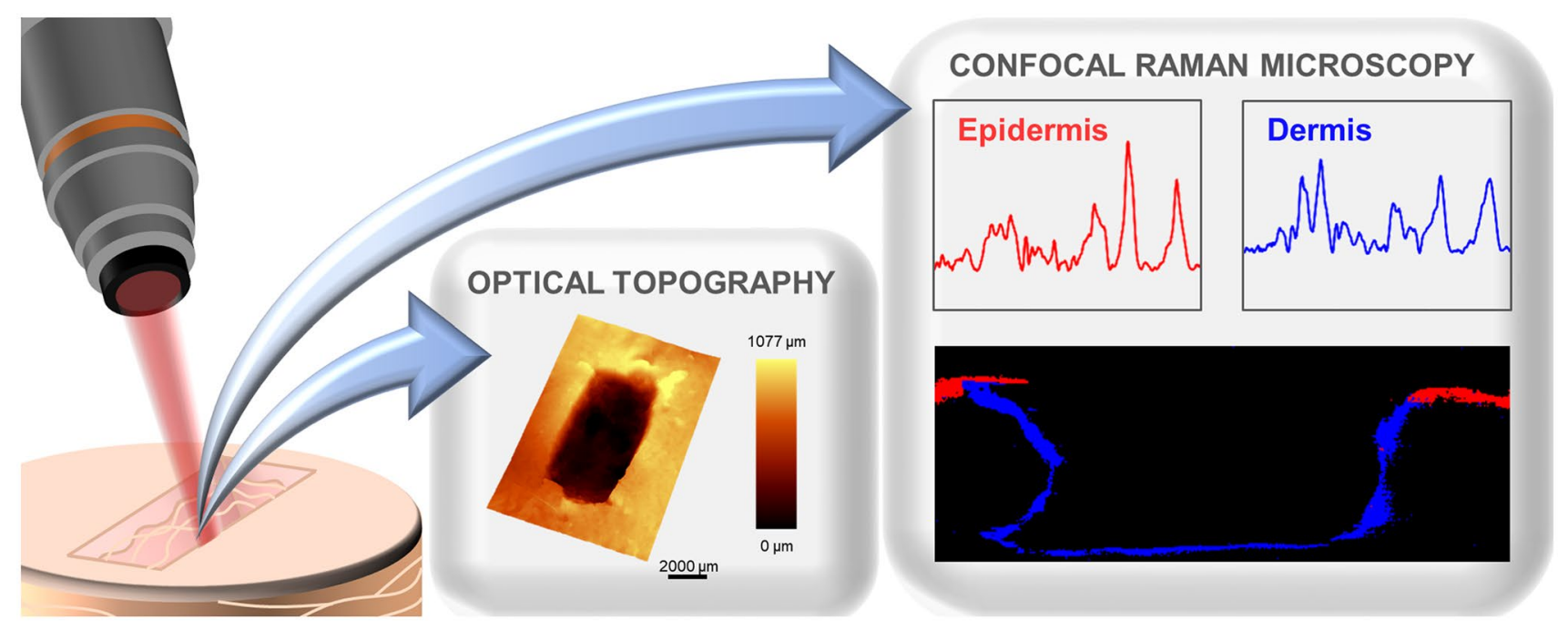

Fig. 6 Noninvasive measurement of a wound model, resulting in a three-dimensional visualization of the wound with optical topography and different Raman spectra for the epidermis and dermis, as well as a false-color Raman image of a virtual section of the wound 
additionally allows for examining individual cells, biological tissues, and pathophysiological changes within tissues. Raman spectra of biological molecules reveal a chemically selective fingerprint peak pattern, containing information about the sample's composition and interactions (Fig. 6). Due to these advantages, CRM has already been used for various skin applications, from the analysis of physiological component distribution in skin tissue to the diagnosis of pathological states and the identification of wound healing stages [186, 187]. CRM is a promising technique to monitor the interaction between human skin cells and biofilm at the cellular level and the impact of biofilm on wound healing over time in a noninvasive way.

Further analytical techniques suitable for the noninvasive time-dependent wound analysis are optical coherence tomography (OCT), high-frequency ultrasound (HFUS), in vivo fluorescence laser scanning microscopy (FLSM), magnetic resonance imaging (MRI), multispectral polarized light imaging (MPLI), terahertz imaging (TI), and near-infrared spectroscopy (NIR) [188, 189]. OCT measures the optical pathway from backscattered light to image biological tissue [188, 190, 191]. Kuck et al. assess OCT as insufficiently established to replace histological sections, since it is not possible to reveal the whole complexity of wound healing. However, OCT might offer the possibility of reducing skin biopsies for monitoring purposes [188]. In comparison to HFUS, which uses backscattered ultrasonic waves instead of light, Vogt et al. concluded that OCT shows a better resolution, while HFUS offers the advantage of a less restricted field-of-view [191]. The resolution of FLSM is comparable to histological analysis, though the penetration depends on the laser used and is often limited to the epidermis and upper dermis [189, 192]. MPLI combines the detection of reflection, scattering, and transmission at the same time. MPLI images correlate well with histological analysis and can be generated rapidly over large surfaces, but the resolution does not allow for information of the morphology of individual cells or fine structures [193]. MRI allows for the investigation of the behavior of water molecules in vivo by applying a magnetic field [194, 195]. By capturing pulses of electromagnetic radiation, TPI enables skin areas to be mapped within a few minutes. The thickness as well as the hydration level of the stratum corneum can be assessed [196, 197]. IR induces fundamental molecular vibrations, overtone and combination bands of these vibrations can be seen in der NIR region. While IR penetrates only into the uppermost layers of the stratum corneum, NIR also penetrates also the dermal skin layer due to shorter wavelengths [198].

\section{Conclusion and future perspectives}

The incidence of infected wounds is increasing, and so is the economic and humanitarian interest in an effective therapy. Biofilm formation especially in chronic wounds complicates the treatment. While there is a wide range of active ingredients, from antiseptics to antibiotics, they are all associated with relevant disadvantages. Aside the challenge of achieving adequate concentrations at the site of infection, bacteria show increasing resistance against many antibiotics. Antiseptics can be used to avoid the development of resistance; however, they are often cytotoxic to human cells. To circumvent these challenges, suitable drug delivery systems are of particular importance. In recent years, the development has moved away from classic pharmaceutical formulations such as semi-solid and liquid preparations in combination with dry wound dressings towards wound dressings that promote wound healing through a moist environment and even more advanced drug delivery systems like particulate carriers, vesicular carriers, fibers, and microneedles. Although these systems are very promising and offer considerable advantages over state-of-the-art drug delivery systems, in most cases, their applicability in clinical practice has not yet been sufficiently considered, resulting in a lack of translation from academic studies to the clinics.

A particular challenge in the development of effective treatments is the preclinical testing to predict the efficacy, absorption, and safety of new active agents or drug delivery systems in an infected wound environment. Besides examination of isolated in vitro biofilm models, different infected wound models ranging from in vivo over ex vivo to in vitro have been developed. However, the imitation of chronic wounds remains a challenge for all models so far. Within the scope of analytics, the noninvasive techniques of confocal Raman microscopy and optical topography represent promising alternatives to established invasive imaging methods.

In addition, the future development of infected wound therapy should not only concentrate on the delivery of drugs adapted to the wound environment, but should also include in situ analysis of wounds with integrated sensors to allow for monitoring of changes in the wound environment.

In summary, there has been a lot of effort in developing effective treatment options for infected wounds. The combination of a better understanding of the wound environment with effective drug delivery systems will enable the future perspective of a targeted therapy, which can slow down the progression of resistance development while at the same time reducing adverse side effects. The area is currently far from being fully developed, but the broad spectrum of novel approaches provides a promising basis for future research.

Author contribution P.K., J.W., and M.W. conceptualized and wrote the manuscript. 
Funding Open Access funding enabled and organized by Projekt DEAL.

\section{Declarations}

Conflicts of interest The authors declare that they have no conflict of interest.

Open Access This article is licensed under a Creative Commons Attribution 4.0 International License, which permits use, sharing, adaptation, distribution and reproduction in any medium or format, as long as you give appropriate credit to the original author(s) and the source, provide a link to the Creative Commons licence, and indicate if changes were made. The images or other third party material in this article are included in the article's Creative Commons licence, unless indicated otherwise in a credit line to the material. If material is not included in the article's Creative Commons licence and your intended use is not permitted by statutory regulation or exceeds the permitted use, you will need to obtain permission directly from the copyright holder. To view a copy of this licence, visit http://creativecommons. org/licenses/by/4.0/.

\section{References}

1. Jones EM, Cochrane CA, Percival SL. The effect of $\mathrm{pH}$ on the extracellular matrix and biofilms. Adv Wound Care (New Rochelle). 2015. https://doi.org/10.1089/wound.2014.0538.

2. Zhao R, Liang H, Clarke E, Jackson C, Xue M. Inflammation in chronic wounds. Int J Mol Sci. 2016. https://doi.org/10.3390/ ijms 17122085 .

3. Nussbaum SR, Carter MJ, Fife CE, DaVanzo J, Haught R, Nusgart M, Cartwright D. An economic evaluation of the impact, cost, and medicare policy implications of chronic nonhealing wounds. Value Health. 2018. https://doi.org/10.1016/j.jval.2017. 07.007.

4. Bjarnsholt T, Kirketerp-Møller K, Jensen PØ, Madsen KG, Phipps R, Krogfelt K, et al. Why chronic wounds will not heal: a novel hypothesis. Wound Repair Regen. 2008. https://doi.org/ 10.1111/j.1524-475X.2007.00283.x.

5. Malone M, Bjarnsholt T, McBain AJ, James GA, Stoodley P, Leaper $\mathrm{D}$, et al. The prevalence of biofilms in chronic wounds: a systematic review and meta-analysis of published data. J Wound Care. 2017. https://doi.org/10.12968/jowc.2017.26.1.20.

6. Bui UT, Edwards H, Finlayson K. Identifying risk factors associated with infection in patients with chronic leg ulcers. Int Wound J. 2018. https://doi.org/10.1111/iwj.12867.

7. Heinzelmann M, Scott M, Lam T. Factors predisposing to bacterial invasion and infection. Am J Surg. 2002. https://doi. org/10.1016/s0002-9610(01)00866-2.

8. Edwards R, Harding KG. Bacteria and wound healing. Curr Opin Infect Dis. 2004. https://doi.org/10.1097/00001432-20040400000004.

9. Siddiqui AR, Bernstein JM. Chronic wound infection: facts and controversies. Clin Dermatol. 2010. https://doi.org/10.1016/j. clindermatol.2010.03.009.

10. Gjødsbøl K, Christensen JJ, Karlsmark T, Jørgensen B, Klein BM, Krogfelt KA. Multiple bacterial species reside in chronic wounds: a longitudinal study. Int Wound J. 2006. https://doi.org/ 10.1111/j.1742-481X.2006.00159.x.
11. Owens CD, Stoessel K. Surgical site infections: epidemiology, microbiology and prevention. J Hosp Infect. 2008. https://doi. org/10.1016/s0195-6701(08)60017-1.

12. Kirketerp-Møller K, Jensen PØ, Fazli M, Madsen KG, Pedersen $\mathrm{J}$, Moser C, et al. Distribution, organization, and ecology of bacteria in chronic wounds. J Clin Microbiol. 2008. https://doi. org/10.1128/JCM.00501-08.

13. Kalan L, Grice EA. Fungi in the wound microbiome. Adv Wound Care (New Rochelle). 2018. https://doi.org/10.1089/wound.2017. 0756.

14. Leaper DJ, Schultz G, Carville K, Fletcher J, Swanson T, Drake R. Extending the TIME concept: what have we learned in the past 10 years? $\left(^{*}\right)$. Int Wound J. 2012. https://doi.org/10.1111/j. 1742-481X.2012.01097.x.

15. International Wound Infection Institute. Wound infection in clinical practice. Wounds International. 2016.

16. Hall-Stoodley L, Costerton JW, Stoodley P. Bacterial biofilms: from the natural environment to infectious diseases. Nat Rev Microbiol. 2004. https://doi.org/10.1038/nrmicro821.

17. De la Fuente-Núñez C, de, Reffuveille F, Fernández L, Hancock REW. . Bacterial biofilm development as a multicellular adaptation: antibiotic resistance and new therapeutic strategies. Curr Opin Microbiol. 2013. https://doi.org/10.1016/j.mib.2013. 06.013.

18. Percival SL, Bowler PG. Biofilms and their potential role in wound healing. Wounds. 2004;16:234-40.

19. Costerton JW, Stewart PS, Greenberg EP. Bacterial biofilms: a common cause of persistent infections. Science. 1999. https:// doi.org/10.1126/science.284.5418.1318.

20. Madhok BM, Vowden K, Vowden P. New techniques for wound debridement. Int Wound J. 2013. https://doi.org/10.1111/iwj. 12045.

21. White W, Asimus M. Assessment and management of nonviable tissue. In: McGuiness B, Asimus M, Swanson T, editors. Wound management for the advanced practitioner. Victoria: IP Communications; 2014. p. 170-203.

22. Fazli M, Bjarnsholt T, Kirketerp-Møller K, Jørgensen B, Andersen AS, Krogfelt KA, et al. Nonrandom distribution of Pseudomonas aeruginosa and Staphylococcus aureus in chronic wounds. J Clin Microbiol. 2009. https://doi.org/10.1128/JCM. 01395-09.

23. Schultz G, Bjarnsholt T, James GA, Leaper DJ, McBain AJ, Malone $\mathrm{M}$, et al. Consensus guidelines for the identification and treatment of biofilms in chronic nonhealing wounds. Wound Repair Regen. 2017. https://doi.org/10.1111/wrr.12590.

24. Schwartz JA, Goss SG, Facchin F, Avdagic E, Lantis JC. Surgical debridement alone does not adequately reduce planktonic bioburden in chronic lower extremity wounds. J Wound Care. 2014. https://doi.org/10.12968/jowc.2014.23.Sup9.S4.

25. Wolcott RD, Rumbaugh KP, James G, Schultz G, Phillips P, Yang $Q$, et al. Biofilm maturity studies indicate sharp debridement opens a time- dependent therapeutic window. J Wound Care. 2010. https://doi.org/10.12968/jowc.2010.19.8.77709.

26. Cutting KF. Addressing the challenge of wound cleansing in the modern era. Br J Nurs. 2010. https://doi.org/10.12968/bjon.2010. 19.Sup4.48423.

27. Percival SL, Mayer D, Malone M, Swanson T, Gibson D, Schultz G. Surfactants and their role in wound cleansing and biofilm management. J Wound Care. 2017. https://doi.org/10.12968/ jowc.2017.26.11.680.

28. Kaehn K, Eberlein T. In-vitro test for comparing the efficacy of wound rinsing solutions. Br J Nurs. 2009. https://doi.org/10. 12968/bjon.2009.18.Sup4.42727.

29. Lipsky BA, Hoey C. Topical antimicrobial therapy for treating chronic wounds. Clin Infect Dis. 2009. https://doi.org/10.1086/ 644732 . 
30. Wilson JR, Mills JG, Prather ID, Dimitrijevich SD. A toxicity index of skin and wound cleansers used on in vitro fibroblasts and keratinocytes. Adv Skin Wound Care. 2005. https://doi.org/ 10.1097/00129334-200509000-00011.

31. Daeschlein G, Von Woedtke T, Kindel E, Brandenburg R, Weltmann K-D, Jünger M. Antibacterial activity of an atmospheric pressure plasma jet against relevant wound pathogens in vitro on a simulated wound environment. Plasma Process Polym. 2010. https://doi.org/10.1002/ppap.200900059.

32. Klebes M, Ulrich C, Kluschke F, Patzelt A, Vandersee S, Richter $\mathrm{H}$, et al. Combined antibacterial effects of tissue-tolerable plasma and a modern conventional liquid antiseptic on chronic wound treatment. J Biophotonics. 2015. https://doi.org/10.1002/jbio. 201400007.

33. Hawkins D, Houreld N, Abrahamse H. Low level laser therapy (LLLT) as an effective therapeutic modality for delayed wound healing. Ann N Y Acad Sci. 2005. https://doi.org/10.1196/annals. 1352.040 .

34. Nussbaum EL, Lilge L, Mazzulli T. Effects of low-level laser therapy (LLLT) of $810 \mathrm{~nm}$ upon in vitro growth of bacteria: relevance of irradiance and radiant exposure. J Clin Laser Med Surg. 2003. https://doi.org/10.1089/104454703322564497.

35. De Sousa NTA, Gomes RC, Santos MF, Brandino HE, Martinez R, De Jesus Guirro RR. Red and infrared laser therapy inhibits in vitro growth of major bacterial species that commonly colonize skin ulcers. Lasers Med Sci. 2016. https://doi.org/10. 1007/s10103-016-1907-x.

36. Lansdown ABG. Silver. I: Its antibacterial properties and mechanism of action. J Wound Care. 2002. https://doi.org/10. 12968/jowc.2002.11.4.26389.

37. Karinja SJ, Spector JA. Treatment of infected wounds in the age of antimicrobial resistance: contemporary alternative therapeutic options. Plast Reconstr Surg. 2018. https://doi.org/10.1097/PRS. 0000000000004799.

38. Kramer A, Dissemond J, Kim S, Willy C, Mayer D, Papke $\mathrm{R}$, et al. Consensus on wound antisepsis: update 2018. Skin Pharmacol Physiol. 2018. https://doi.org/10.1159/000481545.

39. Szostak K, Czogalla A, Przybyło M, Langner M. New lipid formulation of octenidine dihydrochloride. J Liposome Res. 2018. https://doi.org/10.1080/08982104.2016.1275678.

40. Müller G, Kramer A. Biocompatibility index of antiseptic agents by parallel assessment of antimicrobial activity and cellular cytotoxicity. J Antimicrob Chemother. 2008. https://doi.org/10. 1093/jac/dkn125.

41. Ikeda T, Ledwith A, Bamford $\mathrm{CH}$, Hann RA. Interaction of a polymeric biguanide biocide with phospholipid membranes. Biochim Biophysic Acta Biomembr. 1984. https://doi.org/10. 1016/0005-2736(84)90009-9.

42. Hübner N-O, Kramer A. Review on the efficacy, safety and clinical applications of polihexanide, a modern wound antiseptic. Skin Pharmacol Physiol. 2010. https://doi.org/10.1159/000318264.

43. Bellingeri A, Falciani F, Traspedini P, Moscatelli A, Russo A, Tino G, et al. Effect of a wound cleansing solution on wound bed preparation and inflammation in chronic wounds: a single-blind RCT. J Wound Care. 2016. https://doi.org/10.12968/jowc. 2016. 25.3.160.

44. Bjarnsholt T, Alhede M, Jensen PØ, Nielsen AK, Johansen HK, Homøe P, et al. Antibiofilm properties of acetic acid. Adv Wound Care (New Rochelle). 2015. https://doi.org/10.1089/wound.2014. 0554.

45. Wang L, Bassiri M, Najafi R, Najafi K, Yang J, Khosrovi B, et al. Hypochlorous acid as a potential wound care agent: part I. Stabilized hypochlorous acid: a component of the inorganic armamentarium of innate immunity. J Burns Wounds. 2007;6:e5.
46. De Smet K, van den Plas D, Lens D, Sollie P. Pre-clinical evaluation of a new antimicrobial enzyme for the control of wound bioburden. Wounds. 2009;21:65-73.

47. Cooper RA. Inhibition of biofilms by glucose oxidase, lactoperoxidase and guaiacol: the active antibacterial component in an enzyme alginogel. Int Wound J. 2013. https://doi.org/10. 1111/iwj.12083.

48. Martinotti S, Ranzato E. Honey, wound repair and regenerative medicine. J Funct Biomater. 2018. https://doi.org/10.3390/ jfb9020034.

49. Woollard AC, Tatham KC, Barker S. The influence of essential oils on the process of wound healing: a review of the current evidence. J Wound Care. 2007. https://doi.org/10.12968/jowc. 2007.16.6.27064.

50. Guimarães AC, Meireles LM, Lemos MF, Guimarães MCC, Endringer DC, Fronza M, Scherer R. Antibacterial activity of terpenes and terpenoids present in essential oils. Molecules. 2019. https://doi.org/10.3390/molecules24132471.

51. Vandamme L, Heyneman A, Hoeksema H, Verbelen J, Monstrey S. Honey in modern wound care: a systematic review. Burns. 2013. https://doi.org/10.1016/j.burns.2013.06.014.

52. García-Salinas S, Elizondo-Castillo H, Arruebo M, Mendoza G, Irusta S. Evaluation of the antimicrobial activity and cytotoxicity of different components of natural origin present in essential oils. Molecules. 2018. https://doi.org/10.3390/molecules23061399.

53. Kwakman PHS, Te Velde AA, De Boer L, Vandenbroucke-Grauls CMJE, Zaat SAJ. Two major medicinal honeys have different mechanisms of bactericidal activity. PLoS One. 2011. https:// doi.org/10.1371/journal.pone.0017709.

54. Ait-Ouazzou A, Lorán S, Bakkali M, Laglaoui A, Rota C, Herrera A, et al. Chemical composition and antimicrobial activity of essential oils of Thymus algeriensis, Eucalyptus globulus and Rosmarinus officinalis from Morocco. J Sci Food Agric. 2011. https://doi.org/10.1002/jsfa.4505.

55. Majtan J. Methylglyoxal-a potential risk factor of manuka honey in healing of diabetic ulcers. Evid Based Complement Alternat Med. 2011. https://doi.org/10.1093/ecam/neq013.

56. De Groot AC, Schmidt E. Essential oils, part IV: contact allergy. Dermatitis. 2016. https://doi.org/10.1097/DER.0000000000000197.

57. Zeng Z-P, Jiang J-G. Analysis of the adverse reactions induced by natural product-derived drugs. Br J Pharmacol. 2010. https:// doi.org/10.1111/j.1476-5381.2010.00645.x.

58. Mutschler E, Geisslinger G, Kroemer HK, Menzel S, Ruth P. Mutschler Arzneimittelwirkungen: Lehrbuch der Pharmakologie, der klinischen Pharmakologie und Toxikologie : mit einführenden Kapiteln in die Anatomie, Physiologie und Pathophysiologie. 10th ed. Stuttgart: WVG Wissenschaftliche Verlagsgesellschaft; 2013.

59. Sutherland R, Boon RJ, Griffin KE, Masters PJ, Slocombe B, White AR. Antibacterial activity of mupirocin (pseudomonic acid), a new antibiotic for topical use. Antimicrob Agents Chemother. 1985. https://doi.org/10.1128/AAC.27.4.495.

60. Kretschmar M, Witte W, Hof H. Bactericidal activity of tyrothricin against methicillin-resistant Staphylococcus aureus with reduced susceptibility to mupirocin. Eur J Clin Microbiol Infect Dis. 1996. https://doi.org/10.1007/BF01591370.

61. Mangoni ML, Shai Y. Short native antimicrobial peptides and engineered ultrashort lipopeptides: similarities and differences in cell specificities and modes of action. Cell Mol Life Sci. 2011. https://doi.org/10.1007/s00018-011-0718-2.

62. Epand RM, Epand RF. Lipid domains in bacterial membranes and the action of antimicrobial agents. Biochim Biophysic Acta Biomembr. 2009. https://doi.org/10.1016/j.bbamem.2008.08. 023. 
63. Wimley WC. Describing the mechanism of antimicrobial peptide action with the interfacial activity model. ACS Chem Biol. 2010. https://doi.org/10.1021/cb1001558.

64. Hale JDF, Hancock REW. Alternative mechanisms of action of cationic antimicrobial peptides on bacteria. Expert Rev Anti Infect Ther. 2007. https://doi.org/10.1586/14787210.5.6.951.

65. Mangoni ML, McDermott AM, Zasloff M. Antimicrobial peptides and wound healing: biological and therapeutic considerations. Exp Dermatol. 2016. https://doi.org/10.1111/ exd.12929.

66. Gottrup F, Apelqvist J, Bjansholt T, Cooper R, Moore Z, Peters EJG, Probst S. EWMA document: antimicrobials and nonhealing wounds-evidence controversies and suggestions. J Wound Care. 2013;22(5 Suppl.):S1-92.

67. Boateng JS, Matthews KH, Stevens HNE, Eccleston GM. Wound healing dressings and drug delivery systems: a review. J Pharm Sci. 2008. https://doi.org/10.1002/jps.21210.

68. Dhivya S, Padma VV, Santhini E. Wound dressings - a review. Biomedicine (Taipei). 2015. https://doi.org/10.7603/ s40681-015-0022-9.

69. Dabi S, Haddock T, Hill AS. Adaptive transparent film dressings. J Biomater Appl. 1994. https://doi.org/10.1177/088532829400900101.

70. Bullough L, Johnson S, Forder R. Evaluation of a foam dressing for acute and chronic wound exudate management. Br J Community Nurs. 2015. https://doi.org/10.12968/bjcn.2015.20.Sup9.S17.

71. Agren M. The cytocompatibility of hydrocolloid dressings. J Wound Care. 1997. https://doi.org/10.12968/jowc.1997.6.6.272.

72. Simões D, Miguel SP, Ribeiro MP, Coutinho P, Mendonça AG, Correia IJ. Recent advances on antimicrobial wound dressing: A review. Eur J Pharm Biopharm. 2018. https://doi.org/10.1016/j. ejpb.2018.02.022.

73. Mihai MM, Dima MB, Dima B, Holban AM. Nanomaterials for wound healing and infection control. Materials (Basel). 2019. https://doi.org/10.3390/ma12132176.

74. Dizaj SM, Lotfipour F, Barzegar-Jalali M, Zarrintan MH, Adibkia K. Antimicrobial activity of the metals and metal oxide nanoparticles. Mater Sci Eng C Mater Biol Appl. 2014. https:// doi.org/10.1016/j.msec.2014.08.031.

75. Lemire JA, Harrison JJ, Turner RJ. Antimicrobial activity of metals: mechanisms, molecular targets and applications. Nat Rev Microbiol. 2013. https://doi.org/10.1038/nrmicro3028.

76. Kalishwaralal K, BarathManiKanth S, Pandian SRK, Deepak V, Gurunathan S. Silver nanoparticles impede the biofilm formation by Pseudomonas aeruginosa and Staphylococcus epidermidis. Colloids Surf B Biointerfaces. 2010. https://doi. org/10.1016/j.colsurfb.2010.04.014.

77. Velázquez-Velázquez JL, Santos-Flores A, Araujo-Meléndez J, Sánchez-Sánchez R, Velasquillo C, González C, et al. Antibiofilm and cytotoxicity activity of impregnated dressings with silver nanoparticles. Mater Sci Eng C Mater Biol Appl. 2015. https://doi.org/10.1016/j.msec.2014.12.084.

78. Matter MT, Probst S, Läuchli S, Herrmann IK. Uniting drug and delivery: metal oxide hybrid nanotherapeutics for skin wound care. Pharmaceutics. 2020. https://doi.org/10.3390/ pharmaceutics 12080780.

79. Szmyd R, Goralczyk AG, Skalniak L, Cierniak A, Lipert B, Filon FL, et al. Effect of silver nanoparticles on human primary keratinocytes. Biol Chem. 2013. https://doi.org/10. 1515/hsz-2012-0202.

80. Yang Y, Qin Z, Zeng W, Yang T, Cao Y, Mei C, Kuang Y. Toxicity assessment of nanoparticles in various systems and organs. Nanotechnol Rev. 2017. https://doi.org/10.1515/ ntrev-2016-0047.

81. Peng Y, Song C, Yang C, Guo Q, Yao M. Low molecular weight chitosan-coated silver nanoparticles are effective for the treatment of MRSA-infected wounds. Int J Nanomedicine. 2017. https://doi.org/10.2147/IJN.S122357.

82. Bagwe RP, Hilliard LR, Tan W. Surface modification of silica nanoparticles to reduce aggregation and nonspecific binding. Langmuir. 2006. https://doi.org/10.1021/la052797j.

83. Hetrick EM, Shin JH, Paul HS, Schoenfisch MH. Antibiofilm efficacy of nitric oxide-releasing silica nanoparticles. Biomaterials. 2009. https://doi.org/10.1016/j.biomaterials. 2009.01.052.

84. Forier K, Raemdonck K, De Smedt SC, Demeester J, Coenye $\mathrm{T}$, Braeckmans K. Lipid and polymer nanoparticles for drug delivery to bacterial biofilms. J Control Release. 2014. https:// doi.org/10.1016/j.jconrel.2014.03.055.

85. Cheow WS, Chang MW, Hadinoto K. Antibacterial efficacy of inhalable levofloxacin-loaded polymeric nanoparticles against E. coli biofilm cells: the effect of antibiotic release profile. Pharm Res. 2010. https://doi.org/10.1007/s11095-010-0142-6.

86. Chereddy KK, Her C-H, Comune M, Moia C, Lopes A, Porporato PE, et al. PLGA nanoparticles loaded with host defense peptide LL37 promote wound healing. J Control Release. 2014. https://doi.org/10.1016/j.jconrel.2014.08.016.

87. Mosselhy DA, Granbohm H, Hynönen U, Ge Y, Palva A, Nordström K, Hannula S-P. Nanosilver-silica composite: prolonged antibacterial effects and bacterial interaction mechanisms for wound dressings. Nanomaterials (Basel). 2017. https://doi.org/10.3390/nano7090261.

88. Tarusha L, Paoletti S, Travan A, Marsich E. Alginate membranes loaded with hyaluronic acid and silver nanoparticles to foster tissue healing and to control bacterial contamination of non-healing wounds. J Mater Sci Mater Med. 2018. https://doi.org/10.1007/s10856-018-6027-7.

89. Augustine R, Kalarikkal N, Thomas S. Electrospun PCL membranes incorporated with biosynthesized silver nanoparticles as antibacterial wound dressings. Appl Nanosci. 2016. https://doi.org/10.1007/s13204-015-0439-1.

90. You C, Li Q, Wang X, Wu P, Ho JK, Jin R, et al. Silver nanoparticle loaded collagen/chitosan scaffolds promote wound healing via regulating fibroblast migration and macrophage activation. Sci Rep. 2017. https://doi.org/10.1038/s41598-017-10481-0.

91. Masood N, Ahmed R, Tariq M, Ahmed Z, Masoud MS, Ali I, et al. Silver nanoparticle impregnated chitosan-PEG hydrogel enhances wound healing in diabetes induced rabbits. Int J Pharm. 2019. https://doi.org/10.1016/j.ijpharm.2019.01.019.

92. Huang K-T, Fang Y-L, Hsieh P-S, Li C-C, Dai N-T, Huang C-J. Non-sticky and antimicrobial zwitterionic nanocomposite dressings for infected chronic wounds. Biomater Sci. 2017. https://doi.org/10.1039/c7bm00039a.

93. Mei L, Lu Z, Zhang W, Wu Z, Zhang X, Wang Y, et al. Bioconjugated nanoparticles for attachment and penetration into pathogenic bacteria. Biomaterials. 2013. https://doi.org/ 10.1016/j.biomaterials.2013.09.045.

94. Arafa MG, El-Kased RF, Elmazar MM. Thermoresponsive gels containing gold nanoparticles as smart antibacterial and wound healing agents. Sci Rep. 2018. https://doi.org/10.1038/ s41598-018-31895-4.

95. Yang X, Yang J, Wang L, Ran B, Jia Y, Zhang L, et al. Pharmaceutical intermediate-modified gold nanoparticles: against multidrug-resistant bacteria and wound-healing application via an electrospun scaffold. ACS Nano. 2017. https://doi.org/10.1021/acsnano.7b01240.

96. Zhao X, Jia Y, Li J, Dong R, Zhang J, Ma C, et al. Indole derivative-capped gold nanoparticles as an effective bactericide in vivo. ACS Appl Mater Interfaces. 2018. https://doi.org/10. 1021/acsami.8b11980.

97. Kalita S, Kandimalla R, Bhowal AC, Kotoky J, Kundu $S$. Functionalization of $\beta$-lactam antibiotic on lysozyme 
capped gold nanoclusters retrogress MRSA and its persisters following awakening. Sci Rep. 2018. https://doi.org/10.1038/ s41598-018-22736-5.

98. Wang S, Yan C, Zhang X, Shi D, Chi L, Luo G, Deng J. Antimicrobial peptide modification enhances the gene delivery and bactericidal efficiency of gold nanoparticles for accelerating diabetic wound healing. Biomater Sci. 2018. https://doi.org/10.1039/c8bm00807h.

99. Phan TTV, Huynh T-C, Oh J. Photothermal responsive porous membrane for treatment of infected wound. Polymers (Basel). 2019. https://doi.org/10.3390/polym11101679.

100. El-Batal AI, Al-Hazmi NE, Mosallam FM, El-Sayyad GS. Biogenic synthesis of copper nanoparticles by natural polysaccharides and Pleurotus ostreatus fermented fenugreek using gamma rays with antioxidant and antimicrobial potential towards some wound pathogens. Microb Pathog. 2018. https:// doi.org/10.1016/j.micpath.2018.03.013.

101. Mohandas A, Kumar SPT, Raja B, Lakshmanan V-K, Jayakumar R. Exploration of alginate hydrogel/nano zinc oxide composite bandages for infected wounds. Int J Nanomedicine. 2015. https://doi.org/10.2147/IJN.S79981.

102. Arshad R, Sohail MF, Sarwar HS, Saeed H, Ali I, Akhtar S, et al. ZnO-NPs embedded biodegradable thiolated bandage for postoperative surgical site infection: In vitro and in vivo evaluation. PLoS One. 2019. https://doi.org/10.1371/journal. pone. 0217079 .

103. Niranjan R, Kaushik M, Selvi RT, Prakash J, Venkataprasanna KS, Prema D, et al. PVA/SA/TiO2-CUR patch for enhanced wound healing application: In vitro and in vivo analysis. Int $\mathbf{J}$ Biol Macromol. 2019. https://doi.org/10.1016/j.ijbiomac.2019. 07.125 .

104. Ma X, Cheng Y, Jian H, Feng Y, Chang Y, Zheng R, et al. Hollow, rough, and nitric oxide-releasing cerium oxide nanoparticles for promoting multiple stages of wound healing. Adv Healthc Mater. 2019. https://doi.org/10.1002/adhm.201900256.

105. Arul Selvaraj RC, Rajendran M, Nagaiah HP. Re-potentiation of $\beta$-lactam antibiotic by synergistic combination with biogenic copper oxide nanocubes against biofilm forming multidrugresistant bacteria. Molecules. 2019. https://doi.org/10.3390/ molecules24173055.

106. Chen B, Li F, Zhu XK, Xie W, Hu X, Zan MH, et al. Highly biocompatible and recyclable biomimetic nanoparticles for antibiotic-resistant bacteria infection. Biomater Sci. 2020. https:// doi.org/10.1039/d0bm01397h.

107. Qiao B, Pang Q, Yuan P, Luo Y, Ma L. Smart wound dressing for infection monitoring and NIR-triggered antibacterial treatment. Biomater Sci. 2020. https://doi.org/10.1039/c9bm02060h.

108. Chen X, Liu Y, Lin A, Huang N, Long L, Gang Y, Liu J. Folic acidmodified mesoporous silica nanoparticles with $\mathrm{pH}$-responsiveness loaded with Amp for an enhanced effect against anti-drug-resistant bacteria by overcoming efflux pump systems. Biomater Sci. 2018. https://doi.org/10.1039/c8bm00262b.

109. Dorazilová J, Muchová J, Šmerková K, Kočiová S, Diviš P, Kopel $\mathrm{P}$, et al. Synergistic effect of chitosan and selenium nanoparticles on biodegradation and antibacterial properties of collagenous scaffolds designed for infected burn wounds. Nanomaterials (Basel). 2020. https://doi.org/10.3390/nano10101971.

110. Doostan M, Maleki H, Doostan M, Khoshnevisan K, FaridiMajidi R, Arkan E. Effective antibacterial electrospun cellulose acetate nanofibrous patches containing chitosan/erythromycin nanoparticles. Int J Biol Macromol. 2020. https://doi.org/10. 1016/j.ijbiomac.2020.11.174.

111. Basha M, AbouSamra MM, Awad GA, Mansy SS. A potential antibacterial wound dressing of cefadroxil chitosan nanoparticles in situ gel: Fabrication, in vitro optimization and in vivo evaluation. Int J Pharm. 2018. https://doi.org/10.1016/j. ijpharm.2018.04.021.

112. El-Feky GS, Sharaf SS, El Shafei A, Hegazy AA. Using chitosan nanoparticles as drug carriers for the development of a silver sulfadiazine wound dressing. Carbohydr Polym. 2017. https:// doi.org/10.1016/j.carbpol.2016.11.054.

113. Hu C, Zhang F, Kong Q, Lu Y, Zhang B, Wu C, et al. Synergistic chemical and photodynamic antimicrobial therapy for enhanced wound healing mediated by multifunctional light-responsive nanoparticles. Biomacromolecules. 2019. https://doi.org/10. 1021/acs.biomac.9b01401.

114. Dhal C, Mishra R. In vitro and in vivo evaluation of gentamicin sulphate-loaded PLGA nanoparticle-based film for the treatment of surgical site infection. Drug Deliv Transl Res. 2020. https:// doi.org/10.1007/s13346-020-00730-7.

115. Hasan N, Cao J, Lee J, Naeem M, Hlaing SP, Kim J, et al. PEI/NONOates-doped PLGA nanoparticles for eradicating methicillin-resistant Staphylococcus aureus biofilm in diabetic wounds via binding to the biofilm matrix. Mater Sci Eng C Mater Biol Appl. 2019. https://doi.org/10.1016/j.msec.2019.109741.

116. Kalita S, Devi B, Kandimalla R, Sharma KK, Sharma A, Kalita $\mathrm{K}$, et al. Chloramphenicol encapsulated in poly- $\varepsilon$-caprolactonepluronic composite: nanoparticles for treatment of MRSAinfected burn wounds. Int J Nanomedicine. 2015. https://doi. org/10.2147/IJN.S75023.

117. Lin A, Liu Y, Zhu X, Chen X, Liu J, Zhou Y, et al. Bacteriaresponsive biomimetic selenium nanosystem for multidrugresistant bacterial infection detection and inhibition. ACS Nano. 2019. https://doi.org/10.1021/acsnano.9b05766.

118. Gao G, Jiang Y-W, Jia H-R, Wu F-G. Near-infrared lightcontrollable on-demand antibiotics release using thermo-sensitive hydrogel-based drug reservoir for combating bacterial infection. Biomaterials. 2019. https://doi.org/10.1016/j.biomaterials. 2018.09.045.

119. Zhang J, Xu J, Ma H, Bai H, Liu L, Shu C, et al. Designing an amino-fullerene derivative C70-(EDA) 8 to fight superbacteria. ACS Appl Mater Interfaces. 2019. https://doi.org/10.1021/ acsami.9b01483.

120. Shukla S, Shukla A. Tunable antibiotic delivery from gellan hydrogels. J Mater Chem B. 2018. https://doi.org/10.1039/ c8tb00980e.

121. Nicolosi D, Scalia M, Nicolosi VM, Pignatello R. Encapsulation in fusogenic liposomes broadens the spectrum of action of vancomycin against Gram-negative bacteria. Int J Antimicrob Agents. 2010. https://doi.org/10.1016/j.ijantimicag.2010.01.015.

122. Reimer K, Vogt PM, Broegmann B, Hauser J, Rossbach O, Kramer A, et al. An innovative topical drug formulation for wound healing and infection treatment: in vitro and in vivo investigations of a povidone-iodine liposome hydrogel. Dermatology (Basel). 2000. https://doi.org/10.1159/000018494.

123. Nacucchio MC, Bellora MJ, Sordelli DO, D’Aquino M. Enhanced liposome-mediated activity of piperacillin against staphylococci. Antimicrob Agents Chemother. 1985. https://doi.org/10.1128/ aac.27.1.137.

124. Mugabe C, Azghani AO, Omri A. Liposome-mediated gentamicin delivery: development and activity against resistant strains of Pseudomonas aeruginosa isolated from cystic fibrosis patients. J Antimicrob Chemother. 2005. https://doi.org/10.1093/ jac/dkh518.

125. Hu X, Zhang Y, Xie Z, Jing X, Bellotti A, Gu Z. Stimuliresponsive polymersomes for biomedical applications. Biomacromolecules. 2017. https://doi.org/10.1021/acs.biomac. $6 \mathrm{~b} 01704$.

126. Reimondez-Troitiño S, Alcalde I, Csaba N, Íñigo-Portugués A, De la Fuente M, de, Bech F, , et al. Polymeric nanocapsules: a 
potential new therapy for corneal wound healing. Drug Deliv Transl Res. 2016. https://doi.org/10.1007/s13346-016-0312-0.

127. Hajiahmadi F, Alikhani MY, Shariatifar H, Arabestani MR, Ahmadvand D. The bactericidal effect of lysostaphin coupled with liposomal vancomycin as a dual combating system applied directly on methicillin-resistant Staphylococcus aureus infected skin wounds in mice. Int J Nanomedicine. 2019. https://doi.org/ 10.2147/IJN.S214521.

128. Monteiro N, Martins M, Martins A, Fonseca NA, Moreira JN, Reis RL, Neves NM. Antibacterial activity of chitosan nanofiber meshes with liposomes immobilized releasing gentamicin. Acta Biomater. 2015. https://doi.org/10.1016/j.actbio.2015.02.018.

129. Hurler J, Berg OA, Skar M, Conradi AH, Johnsen PJ, SkalkoBasnet N. Improved burns therapy: liposomes-in-hydrogel delivery system for mupirocin. J Pharm Sci. 2012. https://doi. org/10.1002/jps.23260.

130. Pushparaj Selvadoss P, Nellore J, Balaraman Ravindrran M, Sekar U. Novel pyochelin-based PEGylated liposomes for enhanced delivery of antibiotics against resistant clinical isolates of Pseudomonas aeruginosa. Artif Cells Nanomed Biotechnol. 2018. https://doi.org/10.1080/21691401.2017.1408119.

131. Wardlow R, Bing C, VanOsdol J, Maples D, Ladouceur-Wodzak M, Harbeson M, et al. Targeted antibiotic delivery using low temperature-sensitive liposomes and magnetic resonanceguided high-intensity focused ultrasound hyperthermia. Int $\mathbf{J}$ Hyperthermia. 2016. https://doi.org/10.3109/02656736.2015. 1134818.

132. Chhibber S, Kaur J, Kaur S. Liposome entrapment of bacteriophages improves wound healing in a diabetic mouse MRSA infection. Front Microbiol. 2018. https://doi.org/10.3389/ fmicb.2018.00561.

133. Zhao M, Feng W, Li C, Xiu W, Li M, Liu S, et al. A photothermally-induced $\mathrm{HClO}$-releasing nanoplatform for imaging-guided tumor ablation and bacterial prevention. Biomater Sci. 2020. https://doi.org/10.1039/d0bm01629b.

134. Ternullo S, Gagnat E, Julin K, Johannessen M, Basnet P, Vanić Ž, Škalko-Basnet N. Liposomes augment biological benefits of curcumin for multitargeted skin therapy. Eur J Pharm Biopharm. 2019. https://doi.org/10.1016/j.ejpb.2019.09.016.

135. Gharib A, Faezizadeh Z, Godarzee M. Therapeutic efficacy of epigallocatechin gallate-loaded nanoliposomes against burn wound infection by methicillin-resistant Staphylococcus aureus. Skin Pharmacol Physiol. 2013. https://doi.org/10.1159/000345761.

136. Aytekin AA, Tuncay Tanrıverdi S, Aydın Köse F, Kart D, Eroğlu İ, Özer Ö. Propolis loaded liposomes: evaluation of antimicrobial and antioxidant activities. J Liposome Res. 2020. https://doi.org/ 10.1080/08982104.2019.1599012.

137. Wang J, Windbergs M. Functional electrospun fibers for the treatment of human skin wounds. Eur J Pharm Biopharm. 2017. https://doi.org/10.1016/j.ejpb.2017.07.001.

138. Kalantari K, Afifi AM, Jahangirian H, Webster TJ. Biomedical applications of chitosan electrospun nanofibers as a green polymer - Review. Carbohydr Polym. 2019. https://doi.org/10. 1016/j.carbpol.2018.12.011.

139. Lim S-H, Hudson SM. Synthesis and antimicrobial activity of a water-soluble chitosan derivative with a fiber-reactive group. Carbohydr Res. 2004. https://doi.org/10.1016/j.carres.2003.10. 024.

140. Madureira AR, Sarmento B, Pintado M. Current state of the potential use of chitosan as pharmaceutical excipient. In: Thakur VK, Thakur MK, editors. Handbook of Polymers for Pharmaceutical Technologies. Hoboken, NJ, USA: John Wiley \& Sons, Inc; 2015. pp. 275-297; https://doi.org/10.1002/9781119041450.ch9.

141. Wang J, Planz V, Vukosavljevic B, Windbergs M. Multifunctional electrospun nanofibers for wound application - novel insights into the control of drug release and antimicrobial activity. Eur $\mathbf{J}$
Pharm Biopharm. 2018. https://doi.org/10.1016/j.ejpb.2018.05. 035.

142. Patel S, Konar M, Sahoo H, Hota G. Surface functionalization of electrospun PAN nanofibers with $\mathrm{ZnO}-\mathrm{Ag}$ heterostructure nanoparticles: synthesis and antibacterial study. Nanotechnology. 2019. https://doi.org/10.1088/1361-6528/ab045d.

143. Sy JC, Klemm AS, Shastri VP. Emulsion as a means of controlling electrospinning of polymers. Adv Mater. 2009. https://doi.org/10.1002/adma.200701630.

144. Szentivanyi A, Chakradeo T, Zernetsch H, Glasmacher B. Electrospun cellular microenvironments: Understanding controlled release and scaffold structure. Adv Drug Deliv Rev. 2011. https://doi.org/10.1016/j.addr.2010.12.002.

145. Torres-Giner S, Martinez-Abad A, Gimeno-Alcañiz JV, Ocio MJ, Lagaron JM. Controlled delivery of gentamicin antibiotic from bioactive electrospun polylactide-based ultrathin fibers. Adv Eng Mater. 2012. https://doi.org/10.1002/adem.201180006.

146. Alavarse AC, De Oliveira Silva FW, Colque JT, da Silva VM, Prieto T, Venancio EC, Bonvent J-J. Tetracycline hydrochlorideloaded electrospun nanofibers mats based on PVA and chitosan for wound dressing. Mater Sci Eng C Mater Biol Appl. 2017. https://doi.org/10.1016/j.msec.2017.03.199.

147. Rancan F, Contardi M, Jurisch J, Blume-Peytavi U, Vogt A, Bayer IS, Schaudinn C. Evaluation of drug delivery and efficacy of ciprofloxacin-loaded povidone foils and nanofiber mats in a woundinfection model based on ex vivo human skin. Pharmaceutics. 2019. https://doi.org/10.3390/pharmaceutics11100527.

148. Chen J, Liu Z, Chen M, Zhang H, Li X. Electrospun gelatin fibers with a multiple release of antibiotics accelerate dermal regeneration in infected deep burns. Macromol Biosci. 2016. https://doi.org/10.1002/mabi.201600108.

149. Kimna C, Tamburaci S, Tihminlioglu F. Novel zein-based multilayer wound dressing membranes with controlled release of gentamicin. J Biomed Mater Res B Appl Biomater. 2019. https:// doi.org/10.1002/jbm.b.34298.

150. Dhand C, Venkatesh M, Barathi VA, Harini S, Bairagi S, Goh Tze Leng E, et al. Bio-inspired crosslinking and matrix-drug interactions for advanced wound dressings with long-term antimicrobial activity. Biomaterials. 2017. https://doi.org/10. 1016/j.biomaterials.2017.05.043.

151. Su Y, Wang H, Mishra B, Lakshmaiah Narayana J, Jiang J, Reilly DA, et al. Nanofiber dressings topically delivering molecularly engineered human cathelicidin peptides for the treatment of biofilms in chronic wounds. Mol Pharm. 2019. https://doi.org/ 10.1021/acs.molpharmaceut.8b01345.

152. Worsley A, Vassileva K, Tsui J, Song W, Good L. Polyhexamethylene biguanide: polyurethane blend nanofibrous membranes for wound infection control. Polymers (Basel). 2019. https://doi.org/10.3390/polym11050915.

153. Shitole AA, Raut P, Giram P, Rade P, Khandwekar A, Garnaik $B$, Sharma N. Poly (vinylpyrrolidone)-iodine engineered poly ( $\varepsilon$-caprolactone) nanofibers as potential wound dressing materials. Mater Sci Eng C Mater Biol Appl. 2020. https:// doi.org/10.1016/j.msec.2020.110731.

154. Garcia-Salinas S, Gámez E, Landa G, Arruebo M, Irusta S, Mendoza G. Antimicrobial wound dressings against fluorescent and methicillin-sensitive intracellular pathogenic bacteria. ACS Appl Mater Interfaces. 2020. https://doi.org/10.1021/ acsami.0c17043.

155. Pandey VK, Ajmal G, Upadhyay SN, Mishra PK. Nano-fibrous scaffold with curcumin for anti-scar wound healing. Int J Pharm. 2020. https://doi.org/10.1016/j.ijpharm.2020.119858.

156. Sequeira RS, Miguel SP, Cabral CSD, Moreira AF, Ferreira P, Correia IJ. Development of a poly(vinyl alcohol)/lysine electrospun membrane-based drug delivery system for improved 
skin regeneration. Int J Pharm. 2019. https://doi.org/10.1016/j. ijpharm.2019.118640.

157. Nogueira F, Karumidze N, Kusradze I, Goderdzishvili M, Teixeira P, Gouveia IC. Immobilization of bacteriophage in wound-dressing nanostructure. Nanomedicine. 2017. https:// doi.org/10.1016/j.nano.2017.08.008.

158. Sun L, Song L, Zhang X, Zhou R, Yin J, Luan S. Poly( $\gamma$-glutamic acid)-based electrospun nanofibrous mats with photodynamic therapy for effectively combating wound infection. Mater Sci Eng C Mater Biol Appl. 2020. https://doi.org/10.1016/j.msec. 2020.110936.

159. Prausnitz MR. Microneedles for transdermal drug delivery. Adv Drug Deliv Rev. 2004. https://doi.org/10.1016/j.addr.2003.10. 023.

160. Caffarel-Salvador E, Kearney M-C, Mairs R, Gallo L, Stewart SA, Brady AJ, Donnelly RF. Methylene blue-loaded dissolving microneedles: potential use in photodynamic antimicrobial chemotherapy of infected wounds. Pharmaceutics. 2015. https:// doi.org/10.3390/pharmaceutics7040397.

161. Ita K. Transdermal delivery of drugs with microneedles: Strategies and outcomes. J Drug Deliv Sci Technol. 2015. https:// doi.org/10.1016/j.jddst.2015.05.001.

162. Xu J, Danehy R, Cai H, Ao Z, Pu M, Nusawardhana A, et al. Microneedle patch-mediated treatment of bacterial biofilms. ACS Appl Mater Interfaces. 2019. https://doi.org/10.1021/acsami. $9 \mathrm{~b} 02578$.

163. Permana AD, Mir M, Utomo E, Donnelly RF. Bacterially sensitive nanoparticle-based dissolving microneedles of doxycycline for enhanced treatment of bacterial biofilm skin infection: a proof of concept study. Int J Pharm X. 2020. https:// doi.org/10.1016/j.ijpx.2020.100047.

164. Su Y, Mainardi VL, Wang H, McCarthy A, Zhang YS, Chen S, et al. Dissolvable microneedles coupled with nanofiber dressings eradicate biofilms via effectively delivering a database-designed antimicrobial peptide. ACS Nano. 2020. https://doi.org/10.1021/ acsnano.0c04527\&ref=pdf.

165. Permana AD, Anjani QK, Sartini, Utomo E, Volpe-Zanutto F, Paredes AJ, et al. Selective delivery of silver nanoparticles for improved treatment of biofilm skin infection using bacteriaresponsive microparticles loaded into dissolving microneedles. Materials Science and Engineering: C. 2021. https://doi.org/10. 1016/j.msec.2020.111786.

166. Frydman GH, Olaleye D, Annamalai D, Layne K, Yang I, Kaafarani HMA, Fox JG. Manuka honey microneedles for enhanced wound healing and the prevention and/or treatment of Methicillin-resistant Staphylococcus aureus (MRSA) surgical site infection. Sci Rep. 2020. https://doi.org/10.1038/ s41598-020-70186-9.

167. Mir M, Permana AD, Ahmed N, Khan GM, Rehman AU, Donnelly RF. Enhancement in site-specific delivery of carvacrol for potential treatment of infected wounds using infection responsive nanoparticles loaded into dissolving microneedles: a proof of concept study. Eur J Pharm Biopharm. 2020. https://doi.org/10. 1016/j.ejpb.2019.12.008.

168. Yi X, Wang C, Yu X, Yuan Z. A novel bacterial biofilms eradication strategy based on the microneedles with antibacterial properties. Procedia CIRP. 2020. https://doi.org/10.1016/j.procir.2020.05.136.

169. Park SY, Lee HU, Lee Y-C, Kim GH, Park EC, Han SH, et al. Wound healing potential of antibacterial microneedles loaded with green tea extracts. Mater Sci Eng C Mater Biol Appl. 2014. https:// doi.org/10.1016/j.msec.2014.06.021.

170. Seth AK, Geringer MR, Hong SJ, Leung KP, Mustoe TA, Galiano RD. In vivo modeling of biofilm-infected wounds: a review. J Surg Res. 2012. https://doi.org/10.1016/j.jss.2012.06.048.
171. Mestas J, Hughes CCW. Of mice and not men: differences between mouse and human immunology. J Immunol. 2004. https://doi.org/ 10.4049/jimmunol.172.5.2731.

172. Summerfield A, Meurens F, Ricklin ME. The immunology of the porcine skin and its value as a model for human skin. Mol Immunol. 2015. https://doi.org/10.1016/j.molimm.2014.10.023.

173. Brackman $\mathrm{G}$, Coenye $\mathrm{T}$. In vitro and in vivo biofilm wound models and their application. Adv Exp Med Biol. 2016. https://doi.org/10. 1007/5584_2015_5002.

174. Yoon DJ, Fregoso DR, Nguyen D, Chen V, Strbo N, Fuentes JJ, et al. A tractable, simplified ex vivo human skin model of wound infection. Wound Repair Regen. 2019. https://doi.org/10.1111/wrr.12712.

175. Shi D, Mi G, Wang M, Webster TJ. In vitro and ex vivo systems at the forefront of infection modeling and drug discovery. Biomaterials. 2019. https://doi.org/10.1016/j.biomaterials.2018.10.030.

176. Shepherd J, Douglas I, Rimmer S, Swanson L, MacNeil S. Development of three-dimensional tissue-engineered models of bacterial infected human skin wounds. Tissue Eng Part C Methods. 2009. https://doi.org/10.1089/ten.tec.2008.0614.

177. Haisma EM, Rietveld MH, De Breij A, van Dissel JT, El Ghalbzouri A, Nibbering PH. Inflammatory and antimicrobial responses to methicillin-resistant Staphylococcus aureus in an in vitro wound infection model. PLoS One. 2013. https://doi.org/ 10.1371/journal.pone.0082800.

178. Harrison-Balestra C, Cazzaniga AL, Davis SC, Mertz PM. A wound-isolated Pseudomonas aeruginosa grows a biofilm in vitro within 10 hours and is visualized by light microscopy. Dermatol Surg. 2003. https://doi.org/10.1046/j.1524-4725.2003.29146.x.

179. Almeida C, Azevedo NF, Santos S, Keevil CW, Vieira MJ. Discriminating multi-species populations in biofilms with peptide nucleic acid fluorescence in situ hybridization (PNA FISH). PLoS One. 2011. https://doi.org/10.1371/journal.pone.0014786.

180. Hammond AA, Miller KG, Kruczek CJ, Dertien J, Colmer-Hamood JA, Griswold JA, et al. An in vitro biofilm model to examine the effect of antibiotic ointments on biofilms produced by burn wound bacterial isolates. Burns. 2011. https://doi.org/10.1016/j.burns. 2010.09.017.

181. Werthén M, Henriksson L, Jensen PØ, Sternberg C, Givskov M, Bjarnsholt T. An in vitro model of bacterial infections in wounds and other soft tissues. APMIS. 2010. https://doi.org/10.1111/j. 1600-0463.2009.02580.x.

182. Thorn RMS, Greenman J. A novel in vitro flat-bed perfusion biofilm model for determining the potential antimicrobial efficacy of topical wound treatments. J Appl Microbiol. 2009. https://doi. org/10.1111/j.1365-2672.2009.04398.x.

183. Sun Y, Dowd SE, Smith E, Rhoads DD, Wolcott RD. In vitro multispecies Lubbock chronic wound biofilm model. Wound Repair Regen. 2008. https://doi.org/10.1111/j.1524-475X.2008. 00434.x.

184. Hurlow J, Blanz E, Gaddy JA. Clinical investigation of biofilm in nonhealing wounds by high resolution microscopy techniques. J Wound Care. 2016. https://doi.org/10.12968/jowc.2016.25.Sup9.S11.

185. Planz V, Franzen L, Windbergs M. Novel in vitro approaches for the simulation and analysis of human skin wounds. Skin Pharmacol Physiol. 2015. https://doi.org/10.1159/000364810.

186. Franzen L, Windbergs M. Applications of Raman spectroscopy in skin research-from skin physiology and diagnosis up to risk assessment and dermal drug delivery. Adv Drug Deliv Rev. 2015. https://doi.org/10.1016/j.addr.2015.04.002.

187. Jain R, Calderon D, Kierski PR, Schurr MJ, Czuprynski CJ, Murphy CJ, et al. Raman spectroscopy enables noninvasive biochemical characterization and identification of the stage of healing of a wound. Anal Chem. 2014. https://doi.org/10.1021/ ac500513t.

188. Kuck M, Strese H, Alawi SA, Meinke MC, Fluhr JW, Burbach GJ, et al. Evaluation of optical coherence tomography as a non-invasive 
diagnostic tool in cutaneous wound healing. Skin Res Technol. 2014. https://doi.org/10.1111/srt.12077.

189. Lange-Asschenfeldt B, Alborova A, Krüger-Corcoran D, Patzelt A, Richter H, Sterry W, et al. Effects of a topically applied wound ointment on epidermal wound healing studied by in vivo fluorescence laser scanning microscopy analysis. J Biomed Opt. 2009. https://doi.org/10.1117/1.3213603.

190. Alborova A, Lademann J, Kramer A, Richter H, Patzelt A, Sterry W, Koch S. In vivo analysis of wound healing by optical methods. GMS Krankenhhyg Interdiszip. 2008;3:Doc10.

191. Vogt M, Knüttel A, Hoffmann K, Altmeyer P, Ermert H. Comparison of high frequency ultrasound and optical coherence tomography as modalities for high resolution and non invasive skin imaging. Biomed Tech (Berl). 2003. https://doi.org/10.1515/bmte. 2003.48.5.116.

192. Swindle LD, Thomas SG, Freeman M, Delaney PM. View of normal human skin in vivo as observed using fluorescent fiber-optic confocal microscopic imaging. J Invest Dermatol. 2003. https://doi. org/10.1046/j.1523-1747.2003.12477.x.

193. Yaroslavsky AN, Barbosa J, Neel V, DiMarzio C, Anderson RR. Combining multispectral polarized light imaging and confocal microscopy for localization of nonmelanoma skin cancer. J Biomed Opt. 2005. https://doi.org/10.1117/1.1854173.
194. Mirrashed F, Sharp JC. In vivo morphological characterisation of skin by MRI micro-imaging methods. Skin Res Technol. 2004. https://doi.org/10.1111/j.1600-0846.2004.00071.x.

195. Richard S, Querleux B, Bittoun J, Jolivet O, Idy-Peretti I, De Lacharriere O, Leveque JL. Characterization of the skin in vivo by high resolution magnetic resonance imaging: water behavior and age-related effects. J Invest Dermatol. 1993. https://doi.org/ 10.1111/1523-1747.ep12472356.

196. Cole BE, Woodward RM, Crawley DA, Wallace VP, Arnone DD, Pepper M. "Terahertz imaging and spectroscopy of human skin in vivo," Proc. SPIE 4276, Commercial and Biomedical Applications of Ultrashort Pulse Lasers; Laser Plasma Generation and Diagnostics, 29 May 2001. https://doi.org/10.1117/12.428010.

197. Pickwell E, Cole BE, Fitzgerald AJ, Pepper M, Wallace VP. In vivo study of human skin using pulsed terahertz radiation. Phys Med Biol. 2004. https://doi.org/10.1088/0031-9155/49/9/001.

198. Lauridsen RK, Everland H, Nielsen LF, Engelsen SB, Nørgaard L. Exploratory multivariate spectroscopic study on human skin. Skin Res Technol. 2003. https://doi.org/10.1034/j.1600-0846.2003. 00014.x.

Publisher's Note Springer Nature remains neutral with regard to jurisdictional claims in published maps and institutional affiliations. 